INTER NATIONAL MONETARY FUND
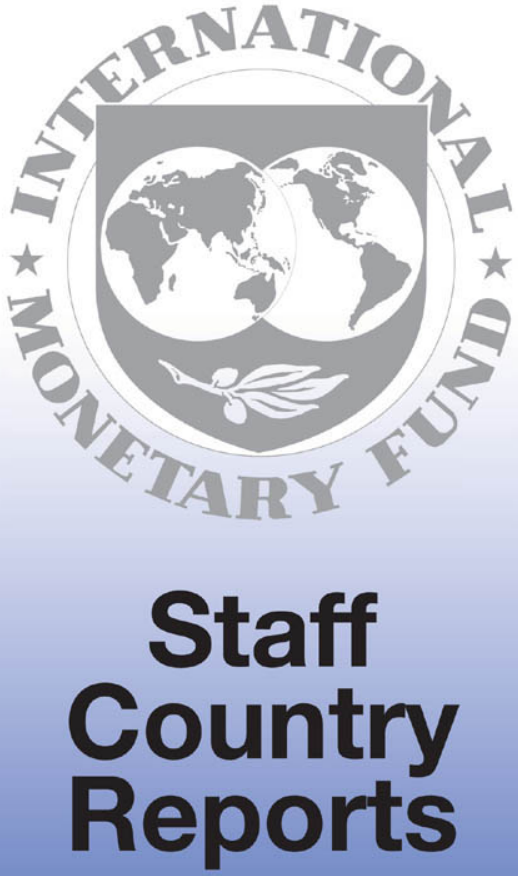


\title{
Republic of Mozambique: Financial Sector Assessment program—Financial System Stability Assessment
}

This Financial System Stability Assessment on the Republic of Mozambique was prepared by a staff team of the International Monetary Fund as background documentation for the periodic consultation with the member country. The views expressed in this document are those of the staff team and do not necessarily reflect the views of the government of the Republic of Mozambique or the Executive Board of the IMF.

The policy of publication of staff reports and other documents by the IMF allows for the deletion of market-sensitive information.

\author{
Copies of this report are available to the public from: \\ International Monetary Fund $\bullet$ Publication Services \\ $70019^{\text {th }}$ Street, N.W. $\bullet$ Washington, D.C. 20431 \\ Telephone: (202) 623-7430 • Telefax : (202) 623-7201 \\ E-mail: publications@imf.org • Internet : http://www.imf.org
}

\section{International Monetary Fund Washington, D.C.}




\title{
INTERNATIONAL MONETARY FUND
}

\section{Republic of Mozambique}

\section{Financial System Stability Assessment—Update}

\author{
Prepared by the Monetary and Capital Markets and African Departments
}

Approved by José Viñals and Antoinette M. Sayeh

June 18, 2009

This Financial System Stability Assessment (FSSA) is based on the work of a joint IMF/World Bank Financial Sector Assessment Program (FSAP) Update mission to Maputo from February 10-23, 2009. The team comprised Dimitri G. Demekas (Mission Chief, IMF), Samuel Maimbo (Deputy Mission Chief, World Bank), Felix Fischer, Ivan Luis de Oliveira Lima, Nicholas Staines, Silvia Iorgova, Pamela Madrid, and Ana Rita Mateus (all IMF); Erik Feyens, José Tuya, Rodolfo Wehrhan, Rekha Reddy, and Alice Zanza (all World Bank). The main findings are as follows:

- As a result of a comprehensive financial sector reform program largely based on the 2003 FSAP recommendations, Mozambique has made significant progress toward developing and strengthening the banking sector, enhancing supervision, and improving central bank operations.

- Despite several government initiatives and legal and regulatory reforms, progress in financial deepening and access has been less satisfactory. Key impediments include economy-wide, structural constraints to financial intermediation, which limit the number of creditworthy clients and increase the costs of financial services; and the lack of competition in the banking system, which reduces deposit mobilization and contributes to high borrowing costs.

- The global financial crisis has not yet directly affected the financial system, although it has clouded the economic outlook and increased macro-financial risks. Near-term vulnerabilities appear contained, as the banking system has limited exposure to market risks and is highly liquid and sufficiently capitalized to withstand credit shocks. Nonetheless, risk monitoring, home-host cooperation, and crisis management arrangements should be strengthened.

- The significant progress made in banking supervision needs to be consolidated by addressing remaining shortcomings. In particular, loan classification and provisioning, risk management guidelines and assessments, as well as the remedial action framework should be strengthened.

The authorities agreed with most of the main recommendations and are preparing plans to implement them, including through technical assistance from both the Bank and Fund.

The main author of this report is Pamela Madrid, with contributions from members of the team.

FSAP assessments are designed to assess the stability of the financial system as a whole and not that of individual institutions. They have been developed to help countries identify and remedy weaknesses in their financial sector structure, thereby enhancing their resilience to macroeconomic shocks and cross-border contagion. FSAP assessments do not cover risks that are specific to individual institutions such as asset quality, operational or legal risks, or fraud. 
Glossary

Executive Summary

I. Macroeconomic Context and Macro-Financial Linkages

II. Financial Sector Structure and Performance.

A. Structure, Depth, and Outreach

III. Banking Sector Soundness and Stability

A. Financial Soundness Indicators and Risk Management.................................. 18

B. Analysis of Current Vulnerabilities and Stress Tests.....................................

IV. Banking Supervision and Financial Safety Nets ......................................................24

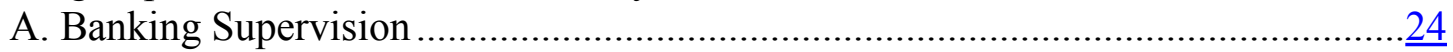

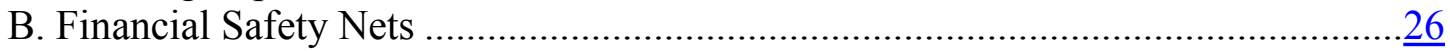

V. Central Bank Operations, Markets and Payments Infrastructure ..................................27

A. Financial Markets and Central Bank Operations ...............................................27

Central bank liquidity management ................................................

Market development ...............................................................

B. Payments System.

Tables

1. Selected Macroeconomic Indicators, 2002-08 ......................................................... 9

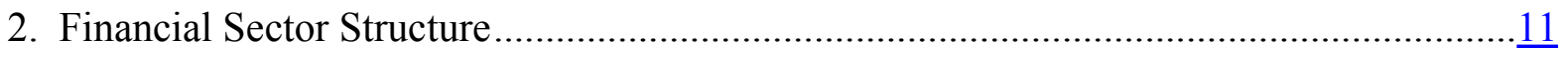

3. Major Banks' Parent Location, Participation, and Rating .............................................. 12

4. Comparison of Selected Bank Commissions (In MT) ..................................................17

5. Price Dispersion of Selected Commissions (In MT) ...............................................17

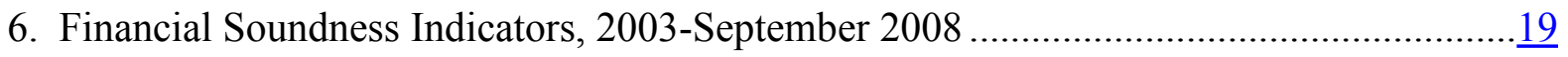

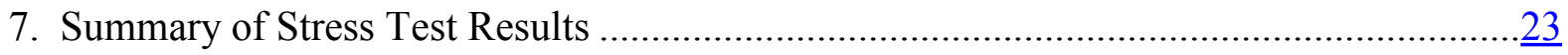

Figures

1. Private Credit Development Benchmarks, 2000-07................................................13

2. Mobilization of savings and intermediation efficiency, 2003-08 .................................13

3. Banking System Concentration, 2008 ................................................................... 15

4. Banking sector efficiency benchmarks, 2000-07 (In percent) ….................................. 15

5. Banking Sector Profitability, 2004-07 (In percent) ................................................. 15

6. Total Ex-Post Interest Rate Margin Spread Decomposition, 2005-07 …........................16 
7. Banking Sector Overhead Costs, 2004-07 (In percent) ……….........................................

8. Monthly Number of Trades and Amount Traded in MMI...............................................

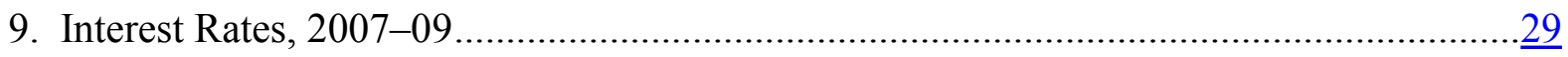

Boxes

1. Implementation Status of 2003 FSAP Recommendation ................................................

2. Mozambique 2009 FSAP Update-Key Recommendation .................................................

3. The Global Financial Turmoil and Mozambique..............................................................

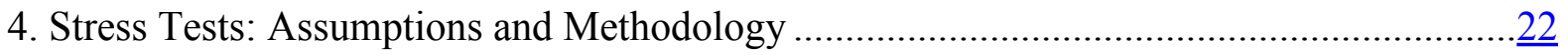

Appendices

I. Observance of Financial Sector Standards and Codes-Summary Assessment of Basel Core Principles for Effective Banking Supervision....................................................

II. A Remedial Action Program for Mozambique ...............................................................44

Appendix Tables

8. Summary Compliance with the Basel Core Principles-Summary Assessments ................41

9. Recommended Action Plan to Improve Compliance with the Basel Core Principles..........42 


\section{GLOSSARY}

\begin{tabular}{|c|c|}
\hline AML & Anti-Money Laundering \\
\hline ATM & Automatic Teller Machine \\
\hline $\mathrm{BCP}$ & Basel Core Principles \\
\hline $\mathrm{BM}$ & Banco de Moçambique \\
\hline BSD & Bank Supervision Department, BM \\
\hline BT & Bilhete do Tesouro-Treasury Bills \\
\hline BVM & Bolsa de Valores de Moçambique-Mozambique Stock Exchange \\
\hline CAR & Capital Adequacy Ratio \\
\hline CEL & Compensação Electronica-Cheque Clearing System \\
\hline CPSIPS & Core Principles for Systemically Important Payment Systems \\
\hline CSD & Central Securities Depository \\
\hline DEE & Departamento de Estudos Económicos-Economic Studies Department, BM \\
\hline DEM & Departamento de Mercados-Markets Department, BM \\
\hline DNS & Deferred Net Settlement \\
\hline DVP & Delivery versus Payment \\
\hline ELA & Emergency Liquidity Assistance \\
\hline FDI & Foreign Direct Investment \\
\hline FPC & Facilidade Permanente de Cedência-BM's Standing Loan Facility \\
\hline FPD & Facilidade Permanente de Depósito-BM's Standing Deposit Facility \\
\hline FSAP & Financial Sector Assessment Program \\
\hline FSTAP & Financial Sector Technical Assistance Project \\
\hline IGS & Inspecção Geral de Seguros_-Inspector General of Insurance \\
\hline IFRS & International Financial Reporting Standards \\
\hline IFS & International Financial Statistics \\
\hline INSS & Instituto Nacional de Segurança Social_-National Institute for Social Security \\
\hline IT & Information Technology \\
\hline $\mathrm{MCI}$ & Mercado Cambial Interbancário_-Interbank Foreign Exchange Market \\
\hline MFI & Microfinance Institution \\
\hline MMI & Mercado Monetário Interbancário-Interbank Metical Market \\
\hline MOF & Ministry of Finance \\
\hline NPL & Nonperforming Loan \\
\hline NPS & National Payment System \\
\hline $\mathrm{OT}$ & Obrigação do Tesouro-Long-Term Treasury Bond \\
\hline PAYGO & Pay as You Go \\
\hline POS & Point of Sale \\
\hline ROAA & Return on Average Assets \\
\hline RTGS & Real-time Gross Settlement \\
\hline SME & Small- and Medium-Size Enterprise \\
\hline STF & Sistema de Transferencia de Fundos do Estado-Govt. Fund Transfer System \\
\hline
\end{tabular}




\section{EXECUTIVE SUMMARY}

1. Since the 2003 FSAP, Mozambique has made significant progress toward developing and strengthening the financial sector and improving central bank operations. The authorities have implemented a comprehensive financial sector reform program largely based on the FSAP recommendations. They promulgated new laws strengthening bank supervisory powers; introduced International Financial Reporting Standards (IFRS) for banks; and laid the foundations for risk-based supervision. Bank soundness was improved through restructuring of problem banks and cleaning up of balance sheets. Enhanced communication and increasing use of market instruments have improved monetary and exchange rate policy implementation, and the level and volatility of real interest rates have declined. Most of the recommendations of the 2003 FSAP have now been implemented (Box 1).

2. However, progress in financial deepening has been less satisfactory. While the ratio of private credit to GDP has increased rapidly, this was from a very low base, and credit is still relatively low in comparison to similar countries. The majority of the population and businesses do not have access to financial services. Non-bank financial intermediaries and corporate debt and equity markets remain small and underdeveloped.

3. The limited progress in financial deepening is attributable to two sets of factors: economy-wide, structural impediments to financial intermediation, which limit the number of creditworthy clients or increase the costs and risks of offering financial services; and the lack of competition in the banking system, which dampens deposit mobilization and contributes to high borrowing costs. Further efforts to improve the debt recovery process, increase credit information, and enhance transparency on service charges would help overcome these obstacles. But these policies would yield results only in the medium- to long-term.

4. Recently, the global crisis has raised new challenges, although the associated financial sector risks for Mozambique appear manageable. The crisis has hitherto not affected directly the Mozambican financial sector. Direct linkages between domestic and foreign financial institutions are limited - although the sizable foreign assets of Mozambican bank subsidiaries in correspondent accounts with their parent banks could be a potential channel for contagion - and the strength of parent banking groups, the domestic banks' limited market and liquidity risk exposures, and the capital controls still in place mitigate associated spillover risks. Lower exports and private capital inflows would slow economic growth and weigh on loan portfolios, especially given their high concentration, making credit risk the most significant source of risk in the system. However, the high levels of capital and strength of the current loan portfolio mean that the Mozambican financial sector is relatively resilient to credit risk - although weaknesses in the loan classification scheme preclude a definitive assessment.

5. Heightened risks call for strengthening risk monitoring, home-host cooperation, and crisis management arrangements. Despite progress in banking supervision, important shortcomings remain, especially in the areas of loan classification and provisioning, 
assessment of risks other than credit — such as liquidity, operational or country risk - and remedial action. Given the predominance of foreign-owned banks in Mozambique, supervisors should enhance home-host coordination to ensure familiarity with the adequacy of capital allocations to the Mozambique operations. Monitoring risk concentration of deposits in parent banks is another area that requires host-home cooperation. The crisis management and bank resolution framework needs to be carefully reviewed, with a particular emphasis in strengthening bank resolution and emergency liquidity assistance policies and instruments. Deposit insurance should be introduced only after key preconditions are in place.

\section{Deeper local money and debt markets would help enhance monetary and}

financial stability and support increased intermediation. The key policy challenge in this area is to improve trading liquidity and provide the basis for a market-based yield curve. Price discovery at treasury bills auctions could be enhanced by ensuring the overnight standing loan facility rate does not act as a ceiling for the treasury bills rates. To spur the government securities market, a first step in developing capital markets, the Treasury should keep a regular presence in the domestic debt market, issuing fixed-rate bonds that would provide the basis for a yield curve beyond one year. The central bank's liquidity management could be improved by adopting a longer-term perspective for achieving monetary targets and using open market operations on a daily basis to better fine-tune liquidity. Issuing fungible treasury bonds to replace some of the outstanding treasury bills would facilitate the central bank's liquidity control.

7. Mozambique has made commendable progress in addressing its national payment system shortcomings, but further follow-through is needed. The priority now is to complete the implementation of the real-time gross settlement (RTGS) system. Before doing so, the central bank needs to finalize outstanding regulations and the operational manual; ensure that the participants fully understand their rights and obligations in the system; and, as a critical provider of liquidity in the RTGS system, ensure that its policies and internal processes are properly aligned to support efficient utilization of liquidity and credit facilities.

8. This FSSA does not discuss in detail the insurance and pensions sectors. Their size and limited linkages with the core banking sector mean that they are not systemically important at this stage. However, these sectors are important from a developmental point of view, were covered during the FSAP mission, and are discussed in the World Bank FSA.

9. Key recommendations are summarized in Box 2 . 


\section{Box 1. Implementation Status of 2003 FSAP Recommendations}

\begin{tabular}{|c|c|c|}
\hline Recommendations & Time frame & Status \\
\hline \multicolumn{3}{|l|}{ Monetary and Foreign Exchange Management } \\
\hline Strengthen BM's analytical capacity. & Continuous & Ongoing \\
\hline Enhance the transparency of monetary policy. & Continuous & Ongoing \\
\hline Introduce weekly primary sales of bills and concentrate their maturities. & Short-term & Partially implemented \\
\hline Reform procedures for daily liquidity management and target bank reserves. & Short-term & Partially implemented \\
\hline Enhance the responsiveness of the exchange rate to deviations from target NIR & Immediate & Fully implemented \\
\hline Experiment with auction sales of foreign exchange. & Medium-term & Fully implemented \\
\hline \multicolumn{3}{|l|}{ Strengthening BM's Financial Independence } \\
\hline Transfer medium and long term foreign (HPIC) debts to the Treasury. & Immediate & Fully implemented \\
\hline Review accounting and profit transfer practices. & Short-term & Fully implemented \\
\hline Introduce a special issue of treasury bills to replace the central bank bills. & Medium-term & Fully implemented \\
\hline \multicolumn{3}{|l|}{ Public Debt Management } \\
\hline $\begin{array}{l}\text { Pass a debt law and formalize coordination between Banco de Moçambique (BM) } \\
\text { and Ministry of Finance (MOF). }\end{array}$ & Short-term & Partially implemented \\
\hline Develop a consolidated T-bill issue program. & Short-term & Pending \\
\hline Exercise call option on Treasury Bonds indexed to Maibor. & Immediate & Fully implemented \\
\hline Simplify and harmonize the taxation of financial investments. & Medium-term & Ongoing \\
\hline \multicolumn{3}{|l|}{ Payment System } \\
\hline Strengthen the payment system unit and firm up the RTGS project. & Continuous & Ongoing \\
\hline Introduce a currency modernization program. & Medium-term & Fully implemented \\
\hline \multicolumn{3}{|l|}{ Supervisory and Market Oversight } \\
\hline Define a transition program towards full adoption of IAS. & Immediate & Fully implemented \\
\hline Establish closer links with foreign shareholders and their supervisors. & Continuous & Ongoing \\
\hline Continue building up the core knowledge of the supervisory staff. & Continuous & Ongoing \\
\hline Strengthen BM's remedial powers. & Short-term & Ongoing \\
\hline \multicolumn{3}{|l|}{ Lending Environment (and Legal Framework) } \\
\hline Enact the proposed amendments to the BM Law and the Banking Law. & Short-term & Fully implemented \\
\hline Review the draft Commercial Code. & Short-term & Fully implemented \\
\hline Modernize the Notary Office and the Public Commercial Registry. & Short-term & Partially implemented \\
\hline Establish a special division of the Maputo City Court to execute judgments. & Short-term & Pending \\
\hline Modernize the Code of Civil Procedure. & Short-term & Fully implemented \\
\hline Update the legal framework for secured transactions. & Medium-term & Pending \\
\hline Consider establishing a specialized commercial court. & Medium-term & Fully implemented \\
\hline \multicolumn{3}{|l|}{ Capital Market, Pensions and Insurance } \\
\hline Build up supervisory capacity. & Continuous & Ongoing \\
\hline Review regulations on capital controls. & Medium-term & Pending \\
\hline Improve accounting and disclosure standards for insurance and pensions. & Short-term & Partially implemented \\
\hline Improve transparency of state pension scheme. & Immediate & Partially implemented \\
\hline $\begin{array}{l}\text { Separate the supervisory and administrative functions of National Institute for } \\
\text { Social Security (INSS). }\end{array}$ & Short-term & Pending \\
\hline \multicolumn{3}{|l|}{ Microfinance } \\
\hline Review draft legislation on microfinance. & Immediate & Fully implemented \\
\hline \multicolumn{3}{|l|}{ Anti-Money Laundering } \\
\hline $\begin{array}{l}\text { Set up an implementation task force. } \\
\text { Prepare a CFT Law. }\end{array}$ & $\begin{array}{l}\text { Immediate } \\
\text { Medium-term }\end{array}$ & $\begin{array}{l}\text { Fully implemented } \\
\text { Ongoing }\end{array}$ \\
\hline
\end{tabular}




\begin{tabular}{|c|c|}
\hline \multicolumn{2}{|l|}{ Box 2. Mozambique 2009 FSAP Update-Key Recommendations } \\
\hline Measure & Timeframe* \\
\hline \multicolumn{2}{|l|}{ Access to Finance } \\
\hline $\begin{array}{l}\text { Standardize bank fees, regularly consolidate and publish fee information } \\
\text { Expand coverage and range of information collected by the credit registry, ensure legal framework } \\
\text { allows private credit registries } \\
\text { Computerize and improve efficiency of property registry } \\
\text { Review and improve transparency of court fee structure }\end{array}$ & Short term \\
\hline $\begin{array}{l}\text { Enact financial reporting legislation covering regulatory aspects of accounting and auditing } \\
\text { Rationalize the regulatory framework for microfinance and develop a capacity building strategy } \\
\text { Discourage bundling of services by banks }\end{array}$ & $\begin{array}{l}\text { Medium } \\
\text { term }\end{array}$ \\
\hline \multicolumn{2}{|l|}{ Banking System Soundness and Supervision } \\
\hline $\begin{array}{l}\text { Monitor international exposures and encourage banks to develop a stress testing framework } \\
\text { Improve loan classification and provisioning rules and review banks' impaired loan models } \\
\text { Introduce remedial action program } \\
\text { Issue guidelines for banks on integrated risk management and supervision by risk }\end{array}$ & Short term \\
\hline $\begin{array}{l}\text { Regulate and/or develop guidance on interest rate, country, liquidity, and market risk } \\
\text { Strengthen crisis preparedness, including internal procedures on emergency liquidity assistance } \\
\text { Ensure legal framework allows for flexible resolution tools, including partial purchase and } \\
\text { assumption or a bridge bank } \\
\text { Introduce deposit insurance after all preconditions are in place } \\
\text { Strengthen cross-border collaboration with home country supervisors }\end{array}$ & $\begin{array}{l}\text { Medium } \\
\text { term }\end{array}$ \\
\hline \multicolumn{2}{|l|}{ Money and Debt Markets and Liquidity Management } \\
\hline $\begin{array}{l}\text { Use overnight repos and reverse repos for BM short-term liquidity intervention } \\
\text { Collateralize standing overnight deposit facility }\end{array}$ & Short term \\
\hline $\begin{array}{l}\text { Extend horizon of liquidity forecast to one year } \\
\text { Increase stock of outstanding OTs through regular auctions; start issuing fixed rate OTs } \\
\text { Issue fungible BTs and OTs and reduce number of outstanding maturities }\end{array}$ & $\begin{array}{l}\text { Medium } \\
\text { term }\end{array}$ \\
\hline \multicolumn{2}{|l|}{ Pensions and Insurance } \\
\hline $\begin{array}{l}\text { Improve INSS governance through introduction of an IT system, publication of financial } \\
\text { statements, and assessment of the value of investment portfolio } \\
\text { Publish outstanding regulations for all pension providers } \\
\text { Test adequacy of financial resources, shareholders, and business plans of insurance companies }\end{array}$ & Short term \\
\hline $\begin{array}{l}\text { Conduct actuarial study of INSS to determine whether parametric changes are necessary } \\
\text { Adopt an explicit investment policy for INSS } \\
\text { Subject INSS and other pension providers to independent supervision } \\
\text { Improve frequency and coverage of data collected by IGS }\end{array}$ & $\begin{array}{l}\text { Medium } \\
\text { term }\end{array}$ \\
\hline \multicolumn{2}{|l|}{ Payment System } \\
\hline $\begin{array}{l}\text { Complete the implementation of RTGS and monitor risks in the CEL } \\
\text { Establish a payment system oversight framework } \\
\text { Introduce interoperability of cards and promote infrastructure sharing in retail payments }\end{array}$ & Short term \\
\hline $\begin{array}{l}\text { Strengthen the staffing in the Payment System Unit } \\
\text { Establish rules for mobile financial services provision, especially payments }\end{array}$ & $\begin{array}{l}\text { Medium } \\
\text { term }\end{array}$ \\
\hline
\end{tabular}

* Short term: up to 12 months; medium term: $1-5$ years. 


\section{MACROECONOMic CONTEXT AND MACRO-FinAnCiAl LinKageS}

10. Mozambique's economy is rich in natural resources, which are the main source of export earnings. A large aluminum smelter is Mozambique's main exporter, accounting for almost half of total receipts, as well as a substantial portion of imports. Other important exports are electricity, gas, cotton, tobacco, and shrimp. Despite the importance of these sectors for foreign exchange inflows (both exports and foreign direct investment (FDI)), the linkages between the large exporters and the domestic economy are still relatively limited.

11. Since the 2003 FSAP, Mozambique's economic performance has been strong. Macroeconomic stability, sustained structural reforms, substantial foreign aid flows and, until recently, a benign international environment generated an average annual real GDP growth rate of $7 \frac{1}{2}$ percent for most of the past decade. Although headline inflation was relatively high and volatile, underlying inflationary pressures were contained Table 1 . The trade deficit has been high (with a spike in 2008 reflecting the world oil prices), but consistent with Mozambique's stage of development and financed by non debt-creating capital inflows.

Table 1. Mozambique: Selected Macroeconomic Indicators, 2002-08

\begin{tabular}{|c|c|c|c|c|c|c|c|}
\hline & $\begin{array}{r}2002 \\
\text { Act. }\end{array}$ & $\begin{array}{r}2003 \\
\text { Act. }\end{array}$ & $\begin{array}{r}2004 \\
\text { Act. }\end{array}$ & $\begin{array}{r}2005 \\
\text { Act. }\end{array}$ & $\begin{array}{r}2006 \\
\text { Act. }\end{array}$ & $\begin{array}{r}2007 \\
\text { Act. }\end{array}$ & $\begin{array}{r}2008 \\
\text { Est. }\end{array}$ \\
\hline Real GDP Growth & 9.2 & 6.5 & 7.9 & 8.4 & 8.7 & 7.0 & 6.8 \\
\hline CPI end-of-period, percent change & 9.1 & 13.8 & 9.1 & 11.2 & 9.4 & 10.3 & 6.2 \\
\hline Current account balance, before grants, percent of GDP & -19.2 & -20.4 & -14.6 & -16.8 & -15.4 & -15.9 & -20.4 \\
\hline Total net aid, percent of GDP & 15.1 & 13.9 & 11.9 & 8.2 & 12.8 & 13.0 & 14.0 \\
\hline Private capital inflows, percent of GDP & 19.1 & 7.7 & 2.7 & 2.6 & 2.7 & 5.7 & 4.0 \\
\hline of which: Foreign direct investment, percent of GDP & 9.0 & 7.3 & 4.3 & 1.6 & 2.1 & 5.3 & 5.9 \\
\hline Gross international reserves, US\$ million & 825 & 947 & 1160 & 1103 & 1241 & 1520 & 1660 \\
\hline Months of import coverage & 5.4 & 5.4 & 5.8 & 4.6 & 4.4 & 5.0 & 4.7 \\
\hline Percent of short-term liabilities & 396 & 401 & 375 & 405 & 57 & 132 & 364 \\
\hline Broad money (M3), percent of GDP & 27.3 & 32.4 & 26.6 & 28.6 & 29.7 & 32.4 & 33.7 \\
\hline of which: Currency outside banks, percent of GDP & 3.5 & 4.3 & 4.1 & 4.0 & 4.0 & 4.3 & 4.0 \\
\hline Private sector credit, stock, percent of GDP & 12.9 & 12.7 & 9.4 & 11.8 & 13.1 & 13.3 & 18.2 \\
\hline Foreign currency deposits, percent of total deposits & 46.7 & 45.0 & 40.1 & 42.1 & 40.3 & 41.8 & 37.7 \\
\hline Foreign currency credit, percent of total private sector credit & 45.9 & 56.3 & 58.4 & 46.7 & 29.3 & 24.4 & 31.6 \\
\hline
\end{tabular}

Source: Mozambican authorities and IMF staff estimates and projections.

\section{This performance largely reflects a prudent and successful macroeconomic}

strategy. Fiscal policy has focused on supporting priority social spending, maintaining debt sustainability, and limiting domestic borrowing in order to avoid crowding out the private sector. Monetary policy has been oriented toward price stability through reserve money targeting in the context of a relatively flexible exchange rate regime. Improvements in monetary management have helped reduce high and volatile real interest rates (identified as a major vulnerability in the 2003 FSAP), while foreign exchange rate operations sought similarly to limit excess exchange rate volatility. Development of the financial sector has advanced in line with a comprehensive financial sector strategy largely based on the 2003 FSAP recommendations. ${ }^{1}$ These policies have garnered substantial donor support and FDI.

\footnotetext{
${ }^{1}$ The authorities, in collaboration with the World Bank, IMF, and donors, developed a comprehensive program supported by the Financial Sector Technical Assistance Project (FSTAP), a five-year project aimed at strengthening several aspects of the financial sector.
} 


\section{Recently, however, the global financial turmoil has clouded the economic outlook and increased macro-financial risks. Box 3 discusses the possible transmission} channels from the global turmoil to the domestic economy and financial sector and provides a prima facie assessment of the risks, pending the more detailed analysis in Section III. In summary, the Mozambican financial sector does not seem vulnerable to market and liquidity risks through direct financial linkages. However, given its reliance on commodity exports and external financing, the economy is now exposed to significant risk through real sector linkages. Lower growth in developed economies could affect Mozambique not only through lower external demand but also through declines in FDI and external aid flows, all of which would dampen growth prospects and increase credit risks for banks.

\section{Box 3. The Global Financial Turmoil and Mozambique}

The crisis could affect a financial sector like Mozambique's through two major transmission channels:

Financial sector linkages (i.e., market risk, liquidity risk, and counterparty credit risk)

- Direct exposure of local banks to securities losses or to illiquid asset and funding markets.

- Exposure to counterparties' with severe losses or illiquidity.

- Sudden stop of capital inflows, with repercussions for bank liquidity and market risk exposures.

- Contagion through parent banks' balance sheets (e.g., impairment of assets held with parents).

- Confidence shock to domestic depositors following bad news about a parent bank or of financial protectionism abroad (e.g., blanket guarantee of deposits in the developed markets).

Real sector linkages (i.e., loan portfolio credit risk)

- Domestic borrowers default due to a decline in income caused by a drop in external demand and/or in export commodity prices.

- Domestic borrowers default due to a sudden stop of capital flows and its impact on income, liquidity, interest rates, and exchange rates.

In the case of Mozambique, exposure to risk through direct financial linkages is low. Direct liquidity risk is limited, as domestic deposits account for more than 90 percent of liabilities for most banks and liquid assets cover more than 50 percent of deposits. Direct market and counterparty risks are also low, as banks' securities portfolios are concentrated in treasury bills and deposits with their parent banks, which were not directly affected by the subprime crisis. The long position in foreign currency for the system as a whole and strict limits on net open positions for banks (less than 20 percent of own funds) protect against direct foreign exchange risk, while high provisioning requirements on lending in foreign currency to non-exporters limit indirect foreign exchange risk. And interest rate risk is limited by the preponderance of short-term and floating rate exposures.

The only possible exception is the risk of financial contagion from banks' exposure to parents which, while very low, cannot be entirely ruled out. Foreign-bank subsidiaries in Mozambique have substantial foreign assets invested with their parent or related correspondent banks. Contagion from weak parent banks could take the form of direct pressures to transfer liquidity, or a rumor about a weak parent sparking a loss of confidence. These contagion channels, however, are constrained by capital controls and the current financial strength of parent banks, while associated risks are mitigated by the banks' high level of liquidity. Furthermore, the BM's gross international reserves far exceed banking system foreign currency deposits.

In contrast, Mozambique is very exposed to real sector linkages. Exports are highly concentrated and the economy is heavily reliant on aid and FDI. A sharp decline in export receipts and/or aid and FDI flows would translate into lower growth and increased credit risk. A major mitigating factor is that shocks propagated through this channel would take time to affect the banking system, providing borrowers, banks, and policy-makers leeway to adjust their business plans and policies. 


\section{Financial Sector Structure and Performance}

\section{A. Structure, Depth, and Outreach}

14. The financial sector is dominated by a few large, foreign banks (Table 2). Banks account for almost all the financial sector's assets, and the 3 largest account for 85 percent of total assets. Almost all major banks are majority-foreign owned, either by Portuguese or other African banks (Table 3), although the government maintains participations in some. Microfinance institutions (MFIs) and micro-banks are small and not systemically important, although they have expanded rapidly in recent years (87 MFIs in 2008, up from 19 in 2003). ${ }^{2}$ This was largely the result of government initiatives to encourage the sector by lowering start-up capital and other costs, particularly in rural areas. However, like the commercial banking sector, the MFI sector is highly concentrated, with four MFIs controlling more than 60 percent of the loan portfolio. The pension sector remains dominated by the obligatory, state-run PAYGO system, although there are a few, small private corporate pension funds. The insurance sector is also small (with claims less than 1 percent of GDP), consisting of 5 private and one majority state-owned company. The stock market is in its infancy, with just 13 listed securities, of which only one is a company equity share.

Table 2. Mozambique: Financial Sector Structure

\begin{tabular}{|c|c|c|c|c|c|c|c|c|c|c|c|c|c|}
\hline & \multicolumn{2}{|c|}{ Dec-03 } & \multicolumn{2}{|c|}{ Dec-04 } & \multicolumn{2}{|c|}{ Dec-05 } & \multicolumn{2}{|c|}{ Dec-06 } & \multicolumn{2}{|c|}{ Dec-07 } & \multicolumn{3}{|c|}{ Latest $20081 /$} \\
\hline & Number & $\begin{array}{c}\text { Total Assets } \\
\text { (Mln. Mt.) }\end{array}$ & Number & $\begin{array}{c}\text { Total Assets } \\
\text { (Mln. Mt.) }\end{array}$ & Number & $\begin{array}{c}\text { Total Assets } \\
\text { (Mln. Mt.) }\end{array}$ & Number & $\begin{array}{c}\text { Total Assets } \\
\text { (Mln. Mt.) }\end{array}$ & Number & $\begin{array}{c}\text { Total Assets } \\
\text { (Mln. Mt.) }\end{array}$ & Number & $\begin{array}{c}\text { Total Assets } \\
\text { (Mln. Mt.) }\end{array}$ & $\begin{array}{l}\text { Percent of } \\
\text { total assets }\end{array}$ \\
\hline Commercial Banks 1/ & 10 & $38,873,396$ & 9 & $42,259,789$ & 9 & $52,408,930$ & 9 & $65,462,016$ & 9 & $79,355,379$ & 11 & $90,592,850$ & 96.0 \\
\hline Private & 10 & $38,873,396$ & 9 & $42,259,789$ & 9 & $52,408,930$ & 8 & $65,125,037$ & 8 & $78,934,392$ & 10 & $90,170,189$ & 95.5 \\
\hline Domestic & - & - & - & - & - & - & - & - & - & - & 1 & 596,518 & 0.6 \\
\hline Foreign & 10 & $38,873,396$ & 9 & $42,259,789$ & 9 & $52,408,930$ & 8 & $65,125,037$ & 8 & $78,934,392$ & 9 & $89,573,671$ & 94.9 \\
\hline State-owned & & & & & & & 1 & 336,979 & 1 & 420,987 & 1 & 422,661 & 0.4 \\
\hline Other depository institutions & 6 & 818,796 & 7 & $1,454,655$ & 8 & $1,673,586$ & 9 & $2,261,082$ & 10 & $2,983,278$ & 10 & $3,084,431$ & 3.3 \\
\hline Credit unions & 4 & 709,264 & 5 & $1,142,876$ & 5 & $1,203,293$ & 6 & $1,351,930$ & 6 & $1,446,809$ & 6 & $1,202,734$ & 1.3 \\
\hline Microfinance institutions 2/ & 2 & 109,532 & 2 & 311,779 & 3 & 470,293 & 3 & 909,152 & 4 & $1,536,469$ & 4 & $1,881,697$ & 2.0 \\
\hline Total depository & 16 & $39,692,192$ & 16 & $43,714,444$ & 17 & $54,082,516$ & 18 & $67,723,098$ & 19 & $82,338,657$ & 21 & $93,677,281$ & 99.2 \\
\hline Other credit institutions & & & & & & & & & & & & & \\
\hline and financial companies $3 /$ & 29 & $2,070,385$ & 29 & $2,270,484$ & 30 & 949,143 & 29 & $1,339,260$ & 27 & 705,448 & 27 & 194,998 & 0.9 \\
\hline Investment Banks & 1 & 63,985 & 1 & 51,749 & - & - & - & - & - & - & - & - & 0.0 \\
\hline Leasing companies & 3 & $1,704,337$ & 3 & $1,869,204$ & 2 & 499,737 & 2 & 753,725 & 1 & 46,644 & 1 & 41,369 & 0.0 \\
\hline Finance companies & 1 & 248,560 & 1 & 345,344 & 1 & 371,786 & 1 & 465,059 & 1 & 524,723 & 1 & NA & 0.6 \\
\hline Securities brokers & 1 & 1,776 & 1 & 1,479 & 1 & 2,574 & 1 & 2,899 & 1 & 3,201 & 1 & 3,201 & 0.0 \\
\hline Others & 2 & 2,332 & 2 & 933 & 2 & 9,906 & 2 & 14,781 & 2 & 15,364 & 2 & 6,912 & 0.0 \\
\hline Foreign exchange houses & 21 & 49,395 & 21 & 1,776 & 24 & 65,139 & 23 & 102,796 & 22 & 115,516 & 22 & 143,516 & 0.2 \\
\hline Institutional investors & 5 & - & 5 & - & 5 & 4,148 & 5 & 5,121 & 6 & 5,525 & 20 & 7,248 & 0.0 \\
\hline Insurance companies & 5 & - & 5 & - & 5 & 4,148 & 5 & 5,121 & 6 & 5,525 & 6 & NA & 0.0 \\
\hline Pension funds & NA & NA & NA & NA & NA & NA & NA & NA & NA & NA & 14 & 7,248 & 0.0 \\
\hline Total financial system & 50 & $41,762,577$ & 50 & $45,984,928$ & 52 & $55,035,806$ & 52 & $69,067,479$ & 52 & $83,049,630$ & 68 & $94,409,775$ & 100.0 \\
\hline
\end{tabular}

${ }^{2}$ This number includes 77 non deposit-taking MFIs that are not included in Table 2, as they do not report assets. 
Table 3. Mozambique: Major Banks' Parent Location, Participation, and Rating

\begin{tabular}{|c|c|c|c|c|c|c|}
\hline Bank & Main Shareholders & $\begin{array}{l}\text { Parent } \\
\text { Country }\end{array}$ & $\begin{array}{l}\text { Participation } \\
\text { Share } \\
\text { (percent) }\end{array}$ & $\begin{array}{r}\text { Fitch } \\
\text { Individual } \\
\text { Rating } 2 /\end{array}$ & $\begin{array}{l}1 / \\
\text { Long- } \\
\text { Term } \\
\text { IDR 3/ }\end{array}$ & Date \\
\hline \multirow{2}{*}{$\begin{array}{l}1 \text { BIM - Banco Internacional de } \\
\text { Moçambique }\end{array}$} & Banco Comercial Português & Portugal & 66.7 & $B$ & $A+$ & Dec. 01, 2008 \\
\hline & Government of Mozambique & & 17.8 & & & \\
\hline \multirow{2}{*}{2 BCl-Fomento } & Caixa Geral de Depositos & Portugal & 42.0 & B & AA- & Oct. 29,2008 \\
\hline & Banco BPI $^{1}$ & Portugal & 30.0 & B & $A+$ & Oct. 3, 2008 \\
\hline 3 Standard Bank, SARL & Standard Bank & South Africa & 96.0 & $\mathrm{~B} / \mathrm{C}$ & A- & Nov. 10,2008 \\
\hline 4 Barclays & Absa Group Limited & South Africa & 80.0 & $\mathrm{~B} / \mathrm{C}$ & $A$ & Nov. 10,2008 \\
\hline 5 African Banking Corp & ABC Holdings Limited & Botswana & 100.0 & - & - & - \\
\hline 6 FNB & FirstRand Group & South Africa & 80.0 & $B / C$ & BBB & Dec. 08,2008 \\
\hline 7 Mauritius Commercial (MCB) & Mauritius Commercial & Mauritius & $>70.0$ & - & - & - \\
\hline $8 \mathrm{ICB}$ & ICB Banking Group & Switzerland & 99.9 & - & - & - \\
\hline 9 ProCredit 4/ & Procredit Holding Ag & Germany & 85.5 & C/D & $C / D$ & Oct. 16, 2008 \\
\hline 12 Oportunidade (BOM) 4/ & $\begin{array}{l}\text { Opportunity Transformation } \\
\text { Investments Inc }\end{array}$ & USA & 59.9 & - & - & - \\
\hline
\end{tabular}

15. Despite the recent expansion in number and size of intermediaries, the depth of bank intermediation is not high. Both deposits-to-GDP and private sector credit-to-GDP, at 25 percent and 12.8 percent, respectively, appear to be around or slightly above the crosscountry benchmarks calculated based on macroeconomic, population and structural variables. ${ }^{3}$ However, compared to the rest of the region, private credit-to-GDP ratio is below average and the loan-to-deposit ratio is particularly low, and up only marginally since the 2003 FSAP (Figures 1 and 2).

\section{The outreach of the banking sector has expanded but access to financial services} remains low and fragmented. The number of bank branches, automatic teller machine (ATMs), and point-of-sale (POS) has grown in recent years, especially in rural and periurban areas. But while large corporates have relatively good access to credit, SMEs and individuals do not (with the exception of salaried employees of corporations that use banks' payroll account services). At 13 percent, the percentage of firms accessing lines of credit is not only low relative to other countries, but has declined from previous surveys in 2002 (29 percent) and 2005 (26 percent). Less than 6 percent of the adult population has credit from a registered financial institution, and just over 10 percent has a savings account. ${ }^{4}$ Rural

\footnotetext{
${ }^{3}$ The model is based on Beck, T., E. Feyen, A. Ize, and F. Moiszeswicz (2008). "Benchmarking financial development," World Bank Research Working Paper 4638.

${ }^{4}$ These estimates were based on credit account and savings account data from regulated institutions and microfinance operators as a proxy for the number of individuals served. Given that clients tend to have more than one deposit account, the number of deposit accounts was adjusted using BM data on deposit structure for unique clients for a sub-sample of financial institutions for 2007.
} 
populations remain particularly underserved: in 2008, branches in rural and peri-urban areas held roughly 20 percent of the number of savings accounts, even though these areas account for over 60 percent of the country's inhabitants.

Figure 1. Mozambique: Private Credit Development Benchmarks, 2000-07
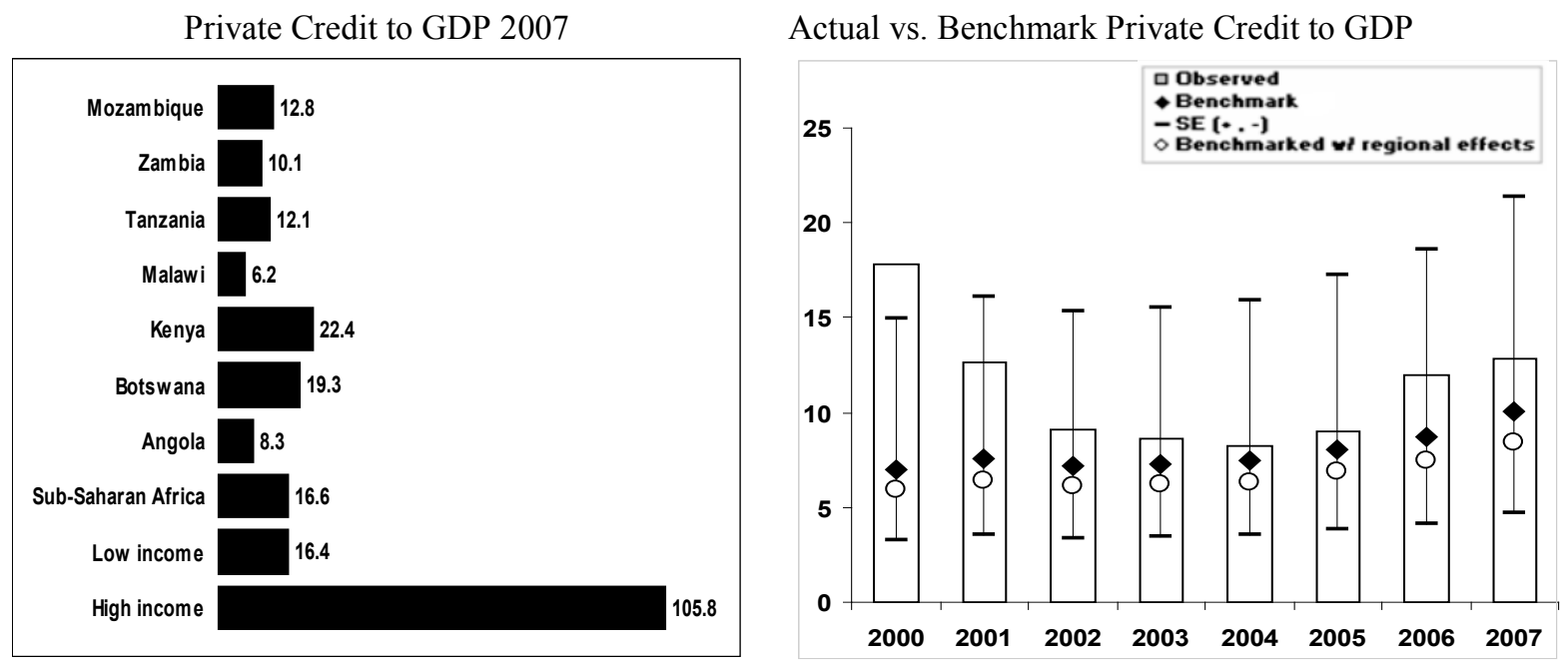

Source: Bank of Mozambique and staff estimates.

Figure 2. Mozambique: Mobilization of Savings and Intermediation Efficiency, 2003-08 (In percent)

Actual vs. Benchmark Deposits to GDP

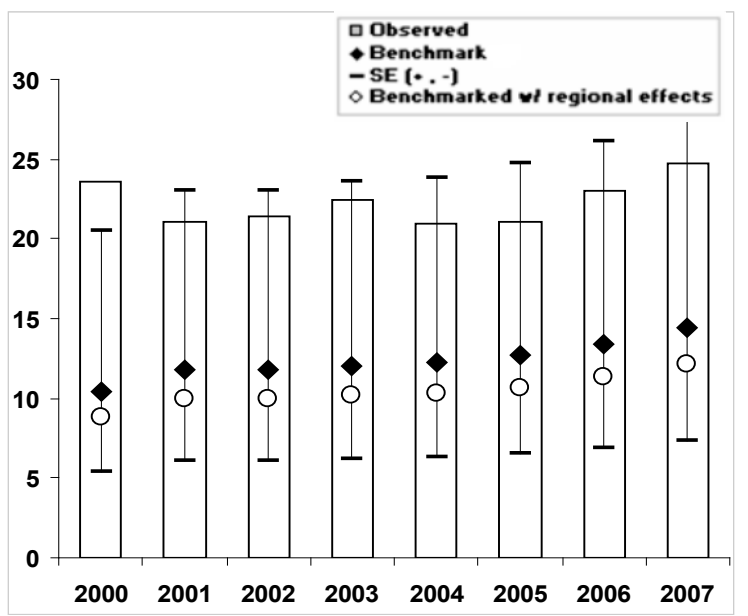

Loan to Deposits

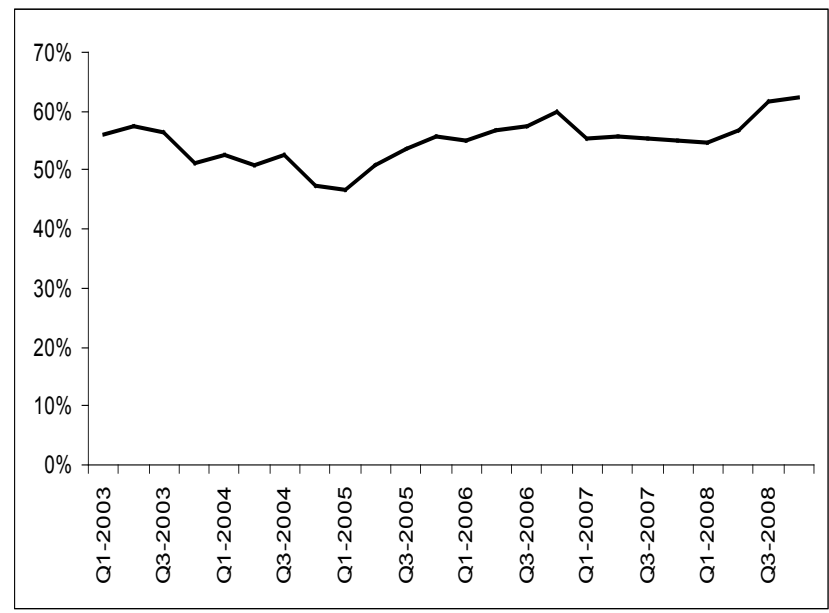

Source: Bank of Mozambique, Bankscope and staff estimates. 


\section{B. What Holds Back Financial Intermediation?}

17. Both economy-wide constraints and the financial sector structure explain the slow progress in financial deepening and financial sector outreach. Economy-wide structural and institutional impediments limit the number of creditworthy clients or increase the costs of extending credit or offering financial services. Specific structural characteristics of the Mozambican banking system hamper competition, reduce incentives to mobilize deposits, and contribute to high borrowing costs.

\section{Economy-wide, structural impediments include:}

- $\quad$ Poor physical access and infrastructure. Unstable electricity supply, poor road conditions, and distance from central bank offices deter rural branch expansion, along with difficulty finding skilled human resources.

- Weaknesses in the legal and regulatory framework. Despite recent improvements, enforcing a contract in Mozambique continues to be costly and slow. ${ }^{5}$ The arbitration center in Maputo - among the most efficient - processes less than 25 cases per year, and fees required to pursue a case are high. A draft bankruptcy law was submitted to Parliament, but has yet to be enacted.

- Weak financial reporting. Credit officers encounter difficulties in obtaining basic cash flow information from SME customers: information provided by smaller firms is often not supported by tax or other independent sources. All firms, including those with foreign participation, suffer from a serious shortage of qualified accountants.

- Problems with the credit and property information infrastructure. The BM's credit risk bureau collects information on individual and corporate borrowers from the 21 regulated financial institutions, but its scope is limited, and it is designed primarily as a prudential monitoring tool. A private registry is currently under consideration, but it is unclear whether the current legal framework allows for private registries. The property registry is also limited - it is estimated that less than 30 percent of properties are registered - and antiquated — still paper-based and not linked electronically between major cities.

19. Structural characteristics of the banking system that impede financial intermediation include:

- $\quad$ Lack of competition. Industry concentration is high (Figure 3); the net interest margin, while declining steadily, is much higher than in comparable countries (Figure 4); and bank profitability is among the highest in the world, and has been steadily increasing since 2004 (Figure 5). These facts suggest lack of competition,

\footnotetext{
${ }^{5}$ World Bank Doing Business Survey, 2008.
} 
Figure 3. Mozambique: Banking System Concentration, 2008

Selected market shares, by commercial bank

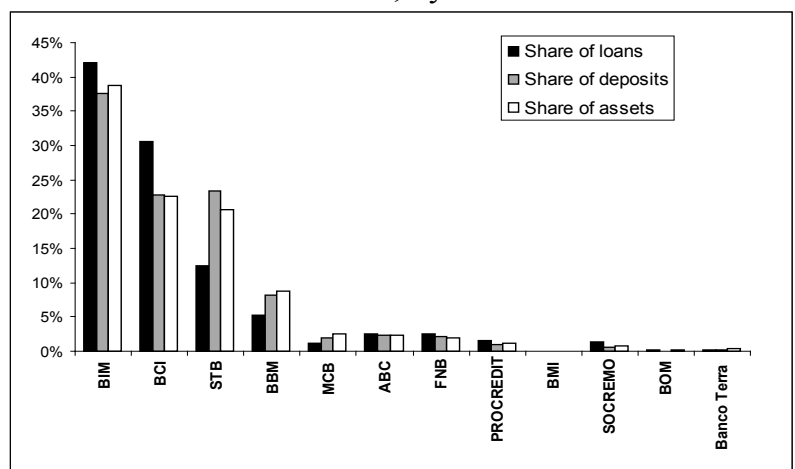

Herfindahl-Hirshman industry concentration index

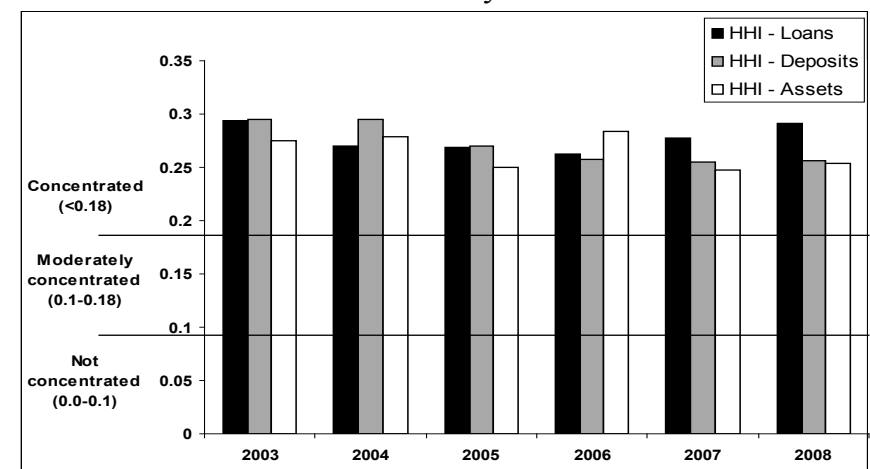

Source: Bank of Mozambique and staff estimates.

Figure 4. Mozambique: Banking sector efficiency benchmarks, 2000-07 (In percent)

Net-interest margin 2007

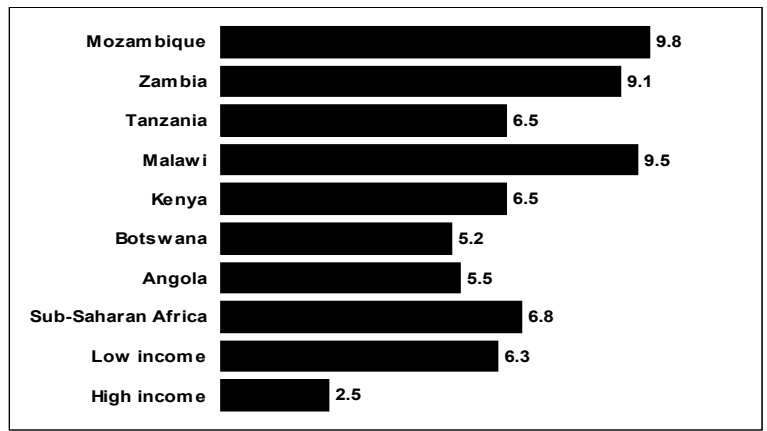

Source: Bank of Mozambique and staff estimates.
Actual vs. benchmark net-interest margin

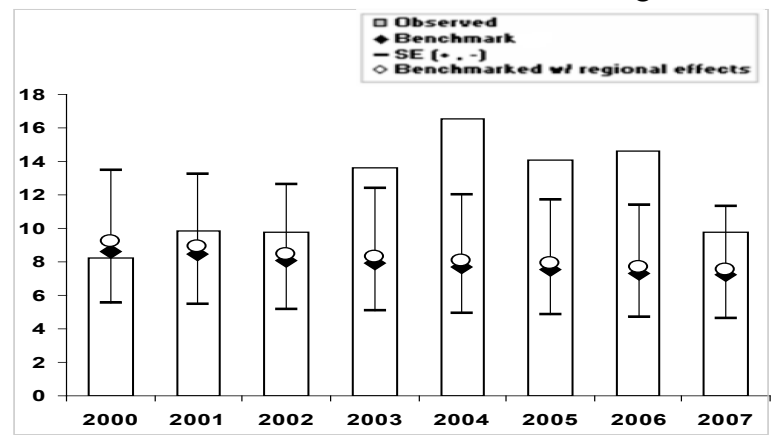

Figure 5. Mozambique: Banking Sector Profitability, 2004-07 (In percent)

Return on average assets (ROAA)

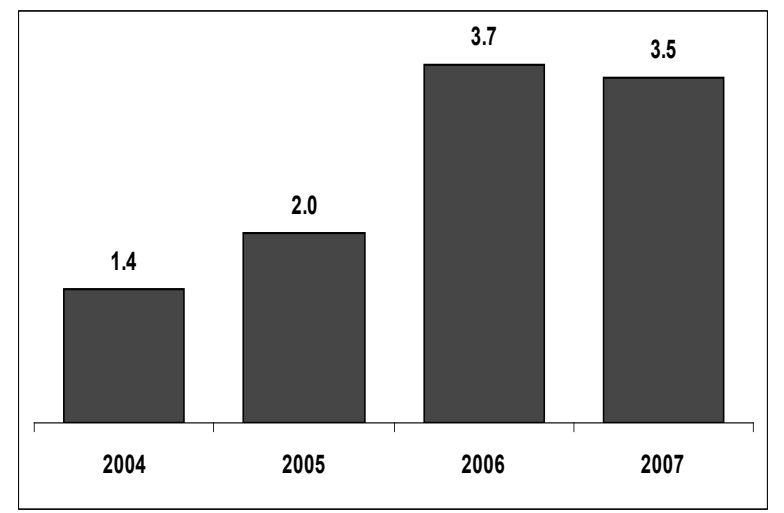

Source: Bank of Mozambique and staff estimates.

\section{ROAA for selected countries in 2007}

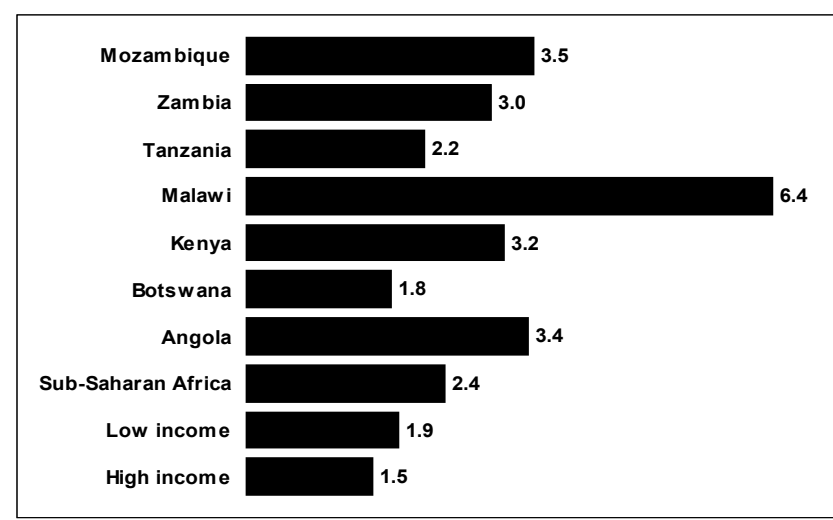


which is corroborated by more formal tests, such as a Rosse-Panzar test; ${ }^{6}$ a BM study showing that lending rates of bigger banks tend to be responsive only to a market leader; ${ }^{7}$ and the analysis of the net interest margin and evidence of pricing power (below).

- High overhead costs. Overhead costs account for over half of the net interest margin (Figure 6) and are higher than other similar countries (Figure 7). High overhead costs can in turn be explained by high input costs (e.g., due to inflexible labor laws), absence of economies of scale, or lack of competitive pressures. The combination of high overhead costs and high profits is another indication of lack of competition.

- High bank commissions and fees. Reflecting lack of competion and economies of scale, commissions are pervasive, not transparent, high compared to peer countries (Tables 4 and 5), ${ }^{8}$ and some have more than doubled since 2003. ${ }^{9}$ The high costs imposed for account maintenance and the mandatory bundling of services by banks inhibit savings mobilization. Since savings serve as an entry point to credit accessbanks typically require a savings history before extending credit - high fees also have a detrimental effect on credit expansion.

Figure 6. Mozambique: Total Ex-Post Interest Rate Margin Spread Decomposition, 2005-07

(In percent)
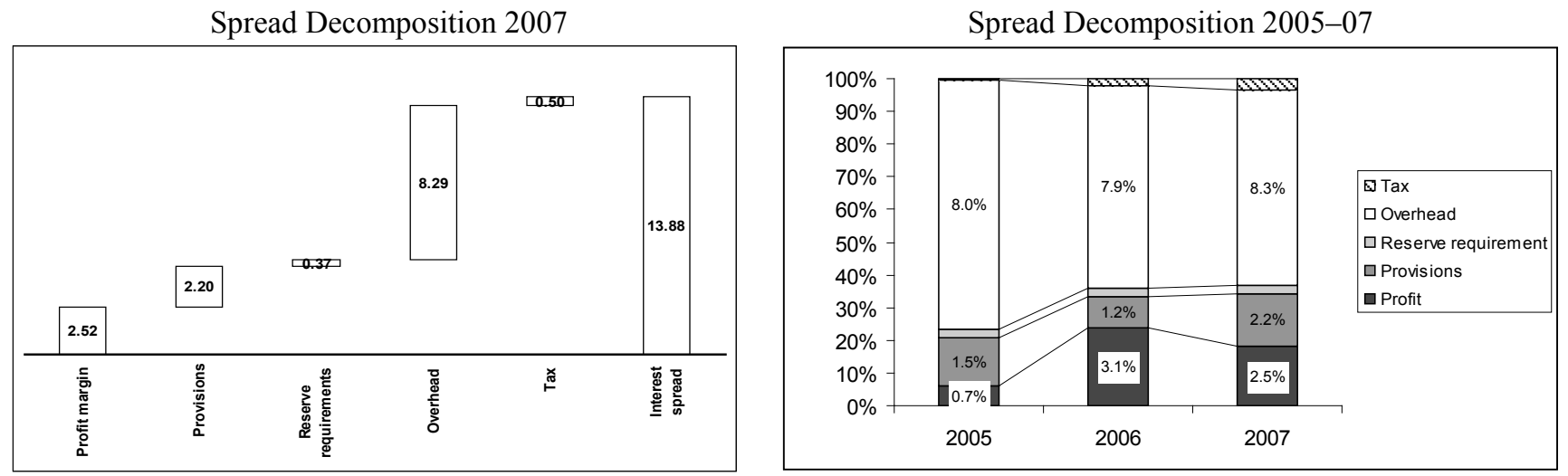

Source: Bank of Mozambique and staff estimates.

\footnotetext{
6 The Rosse-Panzar methodology uses the H-statistic, which measures the sensitivity of total revenue to changes in factor input prices (i.e., pricing power): in perfect competition $(\mathrm{H}=1)$; in a perfect monopoly $(\mathrm{H}<0)$ — see Panzar, John, and James Rosse (1987), “Testing for 'Monopoly' Equilibrium. ” Journal of Industrial Economics Vol. 35, pp. 443-456). Mozambique’s H-statistic is around 0.3.

${ }^{7}$ Bank of Mozambique Research Department, 2007, “Costs of financial intermediation versus profitability of the credit institutions," Maputo.

${ }^{8}$ USAID, 2007, "Financial Sector Constraints on Private Sector Development in Mozambique."

${ }^{9}$ Bank of Mozambique Research Department (2007), op. cit.
} 
Figure 7. Mozambique: Banking Sector Overhead Costs, 2004-07 (In percent)

Overhead Costs vs. Bank System Size, 2005-07

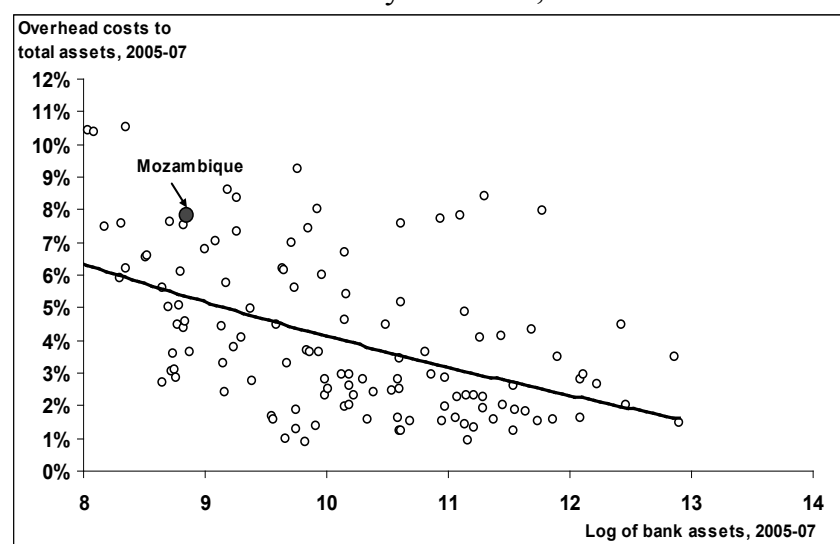

Mozambique Overhead Costs to Assets (BM), 2004-07

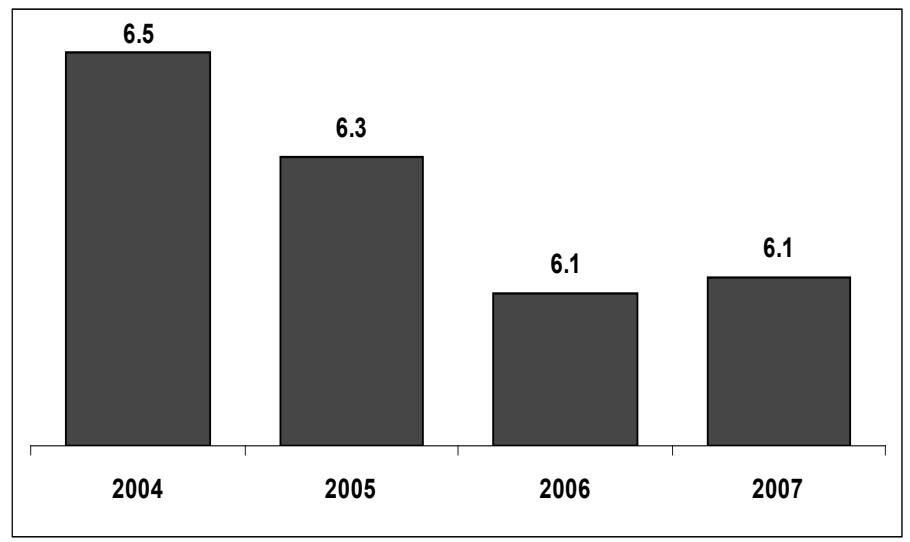

Source: International Financial Statistics, Bankscope, Bank of Mozambique, and staff estimates.

Table 4. Mozambique: Comparison of Selected Bank Commissions (In MT)

\begin{tabular}{llllll}
\hline Commission & Mozambique & South Africa & Botswana & Mauritius & Tanzania \\
\hline Cost of issuing 1 normal check & 12.5 & 1.4 & 1.6 & 1.7 & 1.5 \\
Cost of bouncing check & 1500.0 & 268.7 & 994.3 & 173.2 & 820.1 \\
ATM cash withdrawal & 8.0 & 10.2 & 7.6 & 0.0 & 10.3 \\
Interbank money transfer commission & 500.0 & 35.8 & 104.8 & 0.0 & 130.9 \\
Annual credit card fee & 1820.0 & 394.0 & 381.0 & 86.6 & 380.0 \\
\hline
\end{tabular}

Source: Bank of Mozambique Research Department (2007), "Costs of financial intermediation versus profitability of the credit Institutions" and staff estimates.

Table 5. Mozambique: Price Dispersion of Selected Commissions (In MT)

\begin{tabular}{|c|c|c|}
\hline Commission & Market minimum & Market maximum \\
\hline \multicolumn{3}{|l|}{ General transactions } \\
\hline Close account & 50 & 1000 \\
\hline Consult balance at branch & 7 & 25 \\
\hline Minimum balance violation & 10 & 100 \\
\hline Dormant account penalty & 58 & 615 \\
\hline \multicolumn{3}{|l|}{ Check transactions } \\
\hline Issuance of normal check & 2.97 & 12.5 \\
\hline Issuance of emergency check & 35 & 572 \\
\hline Check deposit & 150 & 337.5 \\
\hline \multicolumn{3}{|l|}{ Transfers } \\
\hline Transfers within bank & 11 & 85 \\
\hline Transfers between banks & 100 & 500 \\
\hline Set up recurring transaction within bank & 8 & 20 \\
\hline Set up recurring transaction between banks & 135 & 260 \\
\hline
\end{tabular}

Source: Bank of Mozambique Research Department (2007). "Costs of financial intermediation versus Profitability of the credit Institutions" and staff estimates. 
20. Removing these impediments to financial intermediation requires policy action across several fronts, much of which is already underway:

- $\quad$ On the legal and regulatory front, continue to encourage alternative disputeresolution mechanisms and out-of-court settlements, the expansion of arbitration services, the establishment of a small claims court and, more generally, the strengthening and modernization of the judiciary, including a review of the court fee structure. The BM should clarify its requirements on mobile banking.

- $\quad$ To strengthen institutional infrastructure and information, the scope of the credit information should be expanded to cover a greater range of information and potential borrowers, and plans to modernize the property registries should be implemented.

- $\quad$ To improve financial reporting, new financing reporting legislation covering all regulatory aspects of accounting and auditing should be enacted, and the Commercial Code accordingly amended. Until the number of qualified accountants in Mozambique has reached a satisfactory level, restrictions on foreign workers in this area should be relaxed.

- $\quad$ Since there are no barriers to entry and the banking market is, in principle, contestable, competition in the banking system can be promoted chiefly through greater transparency on commissions and fees and unbundling of financial services offered by banks. Steps to enhance trading liquidity in the interbank market discussed in Section IV could also contribute to lower interest rates for customers.

21. These measures, however, will yield results only gradually. Many of the impediments reflect the economic realities in a developing country and can only be overcome in the long run. Others, like weaknesses in the property registry, accounting standards, or the judicial system, are already being addressed, but these efforts require time to generate tangible improvements. And the lack of competition in the domestic banking system is to a large extent the result of the small size of the market: as the market grows, competitive pressures will intensify. In the meantime, the best policy for the BM is to maintain macroeconomic stability, continue to strengthen supervision of the banking system, and ensure transparency and a level-playing field. The government should refrain from interfering in credit allocation e.g., through the recently-introduced direct lending scheme by districts.

\section{BANKING SECTOR SOUNDNESS AND STABILITY}

\section{A. Financial Soundness Indicators and Risk Management}

22. Since the 2003 FSAP, banks' asset quality and profitability have improved substantially, although there are some exceptions. System-wide reported nonperformaing loans (NPLs) (as defined by BM regulations - see below) fell from 17.1 percent of total loans in 2003 to 2.8 percent at end-September 2008 (and an estimated 1.8 percent at year-end), 
largely reflecting the restructuring of problem banks and a major clean-up of balance sheets. The latter also resulted in a large jump in reported profitability ratios as bad assets were written-off capital reserves and banks' losses reduced. At the same time, the dollarization of loans and associated foreign currency-induced credit risk declined, largely owing to the introduction of Notice no. $05 / \mathrm{GBM} / 2005$ that requires an initial 50 percent provisioning of foreign currency loans to non-exporters. Mozambican banks are also well capitalized: as of September 2008, all banks fulfilled the minimum required capital adequacy ratio (CAR) of 8 percent, with the average CAR at 13.8 percent of risk-weighted assets (Table 6). Against this overall positive picture, a few small and medium-size banks exhibit weaker asset quality, with NPL ratios twice as high as those of large banks and, in one case, significant underprovisioning.

Table 6. Mozambique: Financial Soundness Indicators, 2003-September 2008

\begin{tabular}{|c|c|c|c|c|c|c|}
\hline & 2003 & 2004 & 2005 & 2006 & 2007 & Sep-08 \\
\hline \multicolumn{7}{|l|}{ Capital Adequacy } \\
\hline Regulatory capital to risk-weighted assets* & 17.0 & 18.7 & 16.0 & 12.5 & 14.2 & 13.8 \\
\hline Regulatory Tier I capital to risk-weighted assets* & 14.7 & 16.0 & 13.6 & 10.7 & 12.3 & 11.3 \\
\hline Capital (net worth) to assets ${ }^{* *} 1 /$ & 8.0 & 8.3 & 7.9 & 8.8 & 9.5 & 10.9 \\
\hline \multicolumn{7}{|l|}{ Asset composition and quality } \\
\hline \multicolumn{7}{|l|}{ Sectoral distribution of loans to total loans* } \\
\hline Agriculture & 12.7 & 9.5 & 8.5 & 6.4 & 9.4 & 9.0 \\
\hline Industry and tourism & 16.9 & 11.9 & 16.8 & 22.2 & 19.5 & 20.0 \\
\hline Construction & 5.2 & 3.4 & 4.1 & 5.6 & 5.7 & 4.5 \\
\hline Commerce & 18.1 & 21.3 & 27.4 & 27.4 & 24.4 & 26.5 \\
\hline Transportation and Communication & 7.1 & 7.2 & 5.8 & 6.2 & 12.2 & 8.8 \\
\hline Other Sectors & 39.9 & 46.8 & 37.4 & 32.3 & 28.7 & 31.2 \\
\hline FX loans to total loans & 69.3 & 64.2 & 53.6 & 34.3 & 29.6 & 33.8 \\
\hline NPLs to gross loans ${ }^{*} 2 /$ & 17.1 & 6.1 & 3.2 & 2.8 & 2.4 & 2.8 \\
\hline NPLs net of provisions to capital ${ }^{*} 2 /$ & 7.9 & 1.7 & 0.9 & 2.2 & 0.2 & 4.6 \\
\hline \multicolumn{7}{|l|}{ Earnings and Profitability } \\
\hline $\mathrm{ROA}^{*} 3 /$ & 1.2 & 1.4 & 1.8 & 3.5 & 3.5 & 3.6 \\
\hline $\mathrm{ROE}^{*} 3 /$ & 16.3 & 18.7 & 27.4 & 55.4 & 47.7 & 44.3 \\
\hline Interest margin to gross income* & 51.5 & 53.4 & 58.0 & 63.1 & 49.4 & 56.8 \\
\hline Noninterest expenses to gross income* & 65.5 & 71.2 & 65.8 & 54.1 & 43.7 & 57.9 \\
\hline Personnel expenses to noninterest expenses & 45.7 & 45.2 & 45.4 & 44.4 & 45.0 & 44.5 \\
\hline Trading and fee income to gross income ${ }^{\star *}$ & 34.6 & 29.5 & 35.0 & 32.2 & 47.5 & 43.1 \\
\hline Spread between reference loan and deposit rates (90 days local currency) & 17.4 & 14.7 & 11.5 & 14.6 & 11.4 & 10.8 \\
\hline \multicolumn{7}{|l|}{ Funding and Liquidity } \\
\hline Liquid assets to total assets ${ }^{\star * *}$ (DAT-C) & 57.7 & 58.1 & 55.5 & 51.9 & 55.9 & 55.9 \\
\hline Customer deposits to total (non-interbank) loans & 251.9 & 243.6 & 189.5 & 180.5 & 191.2 & 183.6 \\
\hline FX liabilities to total liabilities & 46.4 & 41.4 & 45.3 & 42.8 & 43.9 & 43.6 \\
\hline
\end{tabular}

Source: BM and IMF staff estimates based on BM data.

Notes: * Included in the "core set" of FSIs.

** Numbers subject to review.

*** Includes deposits at parent banks.

$1 /$ Net worth is defined as the difference between total assets and total liabilities.

2/ NPLs defined according to Mozambican regulatory standards.

3/ ROA and ROE for September 2008 are on annualized basis. 
23. The system is highly liquid and most banks are not exposed to much funding risk. Metical liquid assets ${ }^{10}$ cover 79 percent of short-term domestic currency liabilities, and foreign assets (mostly deposits at correspondent banks) cover 69 percent of foreign currency deposits. Most banks rely largely on stable retail or corporate deposits, while borrowed foreign funds are limited (less than 1 percent of total assets as of September 2008, much lower than in other countries in the region) as are domestic interbank market funds.

\section{However, concentration risk is significant, as the number of creditworthy} customers is limited. Lending is concentrated in a few sectors, such as energy and commodities. Though lower since the 2003 FSAP, when banks' largest 3 borrowers accounted for more than 50 percent of total loans, concentration risk remains elevated: at some medium-size and small banks, the 20 largest borrowers accounted for as much as 85 percent of all loans at end-2008. While larger banks tend to have more diversified loan books (with the 20 largest borrowers accounting for almost 40 percent of all loans), they are exposed to concentration risk because they have substantial foreign assets deposited in parent or correspondent banks.

\section{Loan classification and provisioning rules do not correspond to international} best practice, although total provisions appear to be adequate. The NPL classification currently used in Mozambique departs from international best practice in two significant ways: first, it classifies as NPL for regulatory purposes only the amounts of principal and interest past due, rather than the entire loan outstanding; and second, it requires banks to classify as nonperforming all amounts past due for any length of time, even one day, rather than the 90 days typically used internationally. The first of these two factors tends to underestimate NPLs; the second tends to exaggerate them. Tentative staff estimates suggest that the quantitative impact of these factors is broadly equivalent, and the "true" level of NPL in the system is around 2.4 percent which, while higher than the reported end-year level (2.1 percent), is still relatively low. Moreover, specific provisions stood at 125 percent of the minimum regulatory requirement - although there was a significant dispersion among banks, with five banks failing to meet the minimum levels and two banks substantially underprovisioned. Finally, required general provisions are an additional 2 percent of loans.

26. Despite the apparent adequacy of provisions, loan classification and provisioning rules should be brought in line with international best practice and risk-based principles. As the above staff estimates are tentative and differences between banks are considerable, the current NPL definition hampers the assessment of the soundness of the banking system and of individual banks; it thus needs to be brought in line with international best practice (see also Basel Core Principles (BCP) assessment). Moreover, the loan classification uses only 3 broad timebands for provisioning of NPLs, with the first for payments overdue between 1-180 days. This does not provide sufficient differentiation for early warning of significant credit deterioration. Classification and provisioning rules should

\footnotetext{
${ }^{10}$ Cash, deposits with the BM, short-term interbank loans, and treasury bill holdings.
} 
also be related to debtor repayment capacity (e.g., based on credit risk assessments), particularly in a system dominated by large corporate borrowers. While the additional 2 percent of general provisions help provide an extra buffer against credit risk, they are not risk-based and therefore distorts the cost of credit (lowering it for the riskiest borrowers and increasing it for the soundest borrowers).

27. Banks' risk management is uneven and their ability to monitor and anticipate risks should be improved. Most large banks do some stress testing or risk sensitivity analysis of their exposures to liquidity or interest rate risks. The most advanced bank uses internal historical data to assess its liquidity risk, and the range of shocks it applies appears large but plausible. However, no bank reported stress testing their loan portfolio. Several banks were relying on the parent banks' models and risk management, providing inputs for group stress tests. While these tests may be sophisticated, they may not adequately reflect Mozambique-specific risks, especially since the Mozambique subsidiary may be a small part of the group. The BM should encourage the development of better stress testing methodologies by banks. It should also build its own capacity-e.g., by collecting and analyzing data on sectoral exposures, probability of default, exposure at default, and loss given default - and review banks' impaired loan models, in particular as it plans to move to Basel II.

28. There are pronounced weaknesses in certain microfinance institutions which, however, do not create systemic risk. Some MFIs and cooperatives have high levels of NPLs and some MFIs (mostly non-deposit taking) are not reporting to the BM as required. Moreover, minimum capital requirements for rural microbanks have been reduced to a level that is extremely low by international standards (MTN 750,000 or about US\$50,000), which might encourage the emergence of unviable institutions. Although the systemic risk created by all these institutions is negligible, this situation can create market distortions and the BM should rationalize the regulatory framework for MFIs and develop a capacity building strategy to promote their sound development.

\section{B. Analysis of Current Vulnerabilities and Stress Tests}

29. Notwithstanding the overall resilience of the Mozambican banking system suggested by the foregoing discussion, banks are vulnerable to credit risk, especially in view of the global financial crisis. As discussed in Box 3, while the banking system is generally insulated from direct financial linkages risks, it is exposed to risk from real sector linkages. Stress tests have thus focused on credit risk, using both a macro-financial scenario analysis and an assessment of concentration risk, but also evaluate liquidity and exchange rate risks. ${ }^{11}$ Box 4 outlines the stress tests and methodology, and the detailed results are presented below and in Table 7.

\footnotetext{
${ }^{11}$ Interest rate risk stress tests could not be conducted due to lack of data.
} 
30. The results suggest that the current level of capitalization of the banking system is sufficiently high to withstand most plausible macroeconomic shocks, although some individual banks would experience significant difficulties. The two scenarios lead to only a moderate decrease in capital adequacy, with CARs under the stand-alone and the combined aid, export, and FDI scenarios dropping to 13.1 percent and 12.6 percent, respectively. While the top three banks have adequate capitalization levels, some medium-size and small banks would be more affected. Under the combined shock, one medium-size bank would see its entire capital depleted, while two other banks' CARs would fall below the required 8 percent minimum. The effects from the single export shock are more muted, with just two banks falling below the 8 percent threshold.

\section{Box 4. Stress Tests: Assumptions and Methodology}

\section{Credit risk I: macro-financial scenario analysis}

To capture the possible effects of the global slowdown on exports and growth, two scenarios are considered (both as deviations from staff baseline projections for 2009): a p drop in total export receipts by 25 percent; and a simultaneous drop in exports, foreign aid, and FDI by 25 percent. The former would represent a major external demand shock, while the latter could be considered an extreme-but-plausible worst-case scenario. Only the direct impact on real GDP growth is taken into account, including the corresponcing drop in imports, though the second-round impact on domestic private investment and consumption is likely to be significant.

Macroeconomic policies and key financial variables, such as interest and exchange rates, are assumed to remain unchanged. Using a simple macroeconomic accounting identity, the impact of the first shock is estimated to be a drop in real GDP growth by 3.4 percentage points on an annual basis, and the impact of the second is 5.6 percentage points. A quarterly regression of the change in the NPLs on real GDP growth and inflation for the period 2003-08 gives an elasticity coefficient for real GDP growth of -3.0, which is used to translate the decline in GDP growth into a deterioration in NPL.

\section{Credit risk II: concentration risk}

These tests evaluate banks' vulnerabilities stemming from high exposures to single obligors. Given the limitations of the large obligor data and the lack of information on current corporate vulnerabilities, the tests analyze the impact of default of each bank's largest, 3 largest, and energy sector obligors.

\section{Liquidity risk}

These tests evaluate banks' liquidity risk by estimating the magnitude of deposit reduction (seperately for total and for private sector deposits) that would deplete completely banks' liquid assets.

\section{Exchange rate risk}

The tests assume exchange rate depreciations of 25 and 50 percent and evaluate the impact of an exchange rate shock on banks' capital adequacy, taking into consideration the magnitude of net foreign currency exposures. The former is broadly in line with observed 12-month percent changes since 2002 (about 30 percent), while the latter is an extreme-but-plausible scenario. 
Table 7. Mozambique: Summary of Stress Test Results

\begin{tabular}{|c|c|c|c|c|}
\hline & Banking System & Top 3 Banks & Medium-Sized Banks & Small Banks \\
\hline \multicolumn{5}{|l|}{ Banking System Structure (before shock) } \\
\hline Number of Analyzed Banks 1/ & 12 & 3 & 5 & 4 \\
\hline Assets/System Assets & 100.0 & 82.4 & 15.6 & 2.1 \\
\hline Regulatory Capital (mln MT) & 7,394 & 5,675 & 955 & 764 \\
\hline CAR & 14.4 & 12.8 & 23.8 & 27.0 \\
\hline \multicolumn{5}{|l|}{ Underestimation of NPLs: Correction } \\
\hline NPL & 2.4 & 1.1 & 12.1 & 6.4 \\
\hline \multicolumn{5}{|c|}{ Underprovisioning: Full Compliance with Provisioning Rules (before shock) } \\
\hline CAR & 13.8 & 12.7 & 17.9 & 25.1 \\
\hline \multicolumn{5}{|l|}{ CREDIT RISK (Over 6 quarters) } \\
\hline $\operatorname{Max} C A R$ & 86.8 & 14.4 & 86.8 & 77.8 \\
\hline NPL & 2.5 & 1.1 & 12.7 & 6.4 \\
\hline \multicolumn{5}{|l|}{ Stress Scenario 2: Export Shock } \\
\hline CAR & 13.1 & 12.4 & 13.9 & 23.6 \\
\hline Min $C A R$ & 6.1 & 10.2 & 6.1 & 7.4 \\
\hline Max $C A R$ & 87.1 & 14.6 & 87.1 & 77.8 \\
\hline NPL & 2.5 & 1.1 & 12.7 & 6.4 \\
\hline \multicolumn{5}{|l|}{ CONCENTRATION RISK } \\
\hline \multicolumn{5}{|c|}{ Stress Scenario 1: Default of largest obligor per bank } \\
\hline CAR & 7.8 & 7.0 & 9.5 & 24.3 \\
\hline \multicolumn{5}{|c|}{ Stress Scenario 1: 25 percent depreciation against theUSD } \\
\hline Min $C A R$ & 10.7 & 10.7 & 11.1 & 11.0 \\
\hline Max CAR & 77.8 & 15.1 & 77.8 & 30.2 \\
\hline Capital Loss/ Gain (in \% of Capital) & 6.0 & 6.4 & 7.6 & -0.2 \\
\hline \multicolumn{5}{|c|}{ Stress Scenario 2: 50 percent depreciation against the USD } \\
\hline CAR & 15.1 & 14.3 & 20.6 & 20.2 \\
\hline Min $C A R$ & 9.6 & 10.4 & 12.6 & 9.6 \\
\hline $\operatorname{Max} C A R$ & 77.9 & 15.5 & 77.9 & 31.7 \\
\hline Capital Loss/Gain (in \% of Capital) & 12.0 & 12.7 & 15.3 & -0.4 \\
\hline \multicolumn{5}{|l|}{ LIQUIDITY RISK 3/ } \\
\hline Liquid Assets (mln MT) 4/ & 27,971 & 22,530 & 5,210 & 231 \\
\hline Liquid Liabilities (mln MT) & 35,304 & 29,428 & 5,365 & 511 \\
\hline Liquidity Ratio 5/ & 79.2 & 76.6 & 97.1 & 45.2 \\
\hline \multicolumn{5}{|c|}{ Stress Scenarios: Size of deposit decreases that lead to complete depletion of liquid assets. } \\
\hline Size of a general deposit decrease & 42.3 & 40.7 & 54.2 & 20.3 \\
\hline Size of decrease of private sector deposits $6 /$ & 77.5 & 76.9 & 81.8 & 55.5 \\
\hline
\end{tabular}

Source: IMF staff estimates based on data from BM.

1/ Due to data constraints, the number of analyzed banks for exchange rate risk is 11 (incl. 3 small banks)

2/ As of September 2008.

3/ Liquid assets include cash, deposits with BoM, domestic and foreign short-term interbank deposits and T-Bills; Liquid liabilities include resources of central banks, short-term deposits and short-term loans from other financial institutions.

4/ The liquidity ratio is defined as the ratio of liquid assets to liquid liabilities.

5 / One bank has a liquidity ratio over 1 , precluding depletion of liquid assets as a result of the assumed shock. 
31. The default of the largest borrowers would be problematic, given banks' concentrated credit portfolios. A stress test of the default and complete write-down of the single largest borrower of each bank shows the system-wide CAR falling to 7.8 percent, with three small and medium-size banks under the minimum capital requirement. The default of the three largest obligors would deplete the capital base of these banks; however, simultaneous failure (and full loss given default) of the largest borrowers across several industries is an extremely low probability event. A more industry-specific shock that assumes the failure of all energy companies among the three largest bank obligors would be more manageable, with the system-wide CAR decreasing to 9 percent.

32. The system is resilient to liquidity and exchange rate shocks. However, some tests were constrained by data deficiencies.

- $\quad$ The stress test for liquidity risk estimates the drop in deposits that would deplete the system's liquid assets in the absence of generally accepted liquidity ratio benchmarks. Since the system is very liquid, this drop would need to be very substantial (around 40 percent). The test results suggest that liquidity risk is low, although the variation across bank groups shows that small banks are more sensitive.

- $\quad$ Direct exchange rate risk test assess the impact of exchange rate shock on banks' net open position in foreign currency and capital adequacy ratios. ${ }^{12}$ Most banks, except for some small banks, are long foreign exchange and would not suffer valuation losses. Indirect foreign exchange credit risk is also limited due to the provisioning requirements on foreign currency loans to non-exporters, which induces banks not to lend to unhedged borrowers.

\section{BAnking Supervision ANd Financial SAFety Nets}

\section{A. Banking Supervision}

33. The supervisory framework and capacity have been significantly enhanced since the 2003 FSAP. Key enhancements include a major revision to the Banking Law; introduction of rules for consolidated supervision; a new inspection manual; promulgation of the AML law; and the implementation of IFRS for banks. Home-host supervisory relationships were also strengthened, either through Memoranda of Understanding (MOU) or informally. Furthermore, Bank Supervision Department, BM (BSD) staff has increased substantially and great emphasis has been placed in training programs.

\section{Today, the BM seems to have a good overview of the Mozambican banking sector as a whole and of individual institutions, but the structure of the system presents}

\footnotetext{
${ }^{12}$ Lack of information on banks' off-balance sheet exposures hampers the analysis of their overall net open position, but given Mozambique's relatively low level of financial sector development, these exposures are likely small.
} 
important challenges. Regular reports and analysis of the financial situation help provide an up-to-date view of each institution, and more detailed insights are acquired through yearly on-site inspections. However, the structure of the Mozambican banking system presents two particular regulatory challenges for the BM. As discussed in Section II, banking system assets are highly concentrated in the four largest banks, all of which are foreign-owned. This implies that first, the BM needs to have strong cross-border collaboration with home country supervisors; and second, in collaboration with home country supervisors, the BM needs to review systems developed at the parent company and determine their applicability and adequacy for the Mozambican branch or subsidiary.

35. The enhanced framework is evidenced in the improved BCP assessment, although shortcomings remain. The $\mathrm{BCP}$ Report on Standards and Codes (ROSC) documents the significant progress made since 2003 -Appendix I. Despite this progress, important shortcomings remain, especially in the areas of loan classification and provisioning, assessments for risks other than credit, and remedial action.

- Loan classification and provisioning. As discussed in Section III, loan classification and provisioning rules should be brought in line with international best practice and be made more risk-based.

- $\quad$ Risk monitoring and management. In contrast to credit risk, interest rate, country, liquidity, and market risks are either not regulated or regulations do not always include guidance for supervisors in monitoring compliance or provide banks with the minimum requirements expected for risk management systems. Although these risks are currently low, these weaknesses should be addressed.

- $\quad$ Prudential regulations. The BM is in the midst of developing a significant amount of guidance to enhance its supervisory process, procedures for monitoring compliance with AML requirements, and guidelines on internal audit. This would also include guidelines on integrated risk management and risk-based supervision. These efforts need to be brought to fruition as soon as possible.

- $\quad$ Remedial action. Although the BM has adequate legal powers to take action in case of banks in difficulties, these powers are not always used effectively, undermining credibility. While minor remedial actions are always taken, the BM is occasionally slow to act when important problems occur, such as insufficient capital or inadequate provisioning. An effective remedial action program, along the lines presented in Annex II, can instill discipline and make remedial steps more systematic and credible.

- $\quad$ Foreign supervisory coordination. The BSD should be familiar with the home country supervisor, the strength of support that may be available from the parent company, the home country rules for bankruptcy, and economic conditions in the home country. With the planned global implementation of Basel II, the BM will need to ensure it is familiar with capital allocations to the Mozambique operations. 
Monitoring risk in the concentration of correspondent deposits in parent banks is another area that requires coordination and familiarity with country risk.

\section{The BM should ensure that adequate resources are dedicated to reviewing} compliance with IFRS and the completion of the supervisory guidance. It should continue to strive for up-to-date training and adequate of human resources in the BSD, and ensure that supervisory capacity is adequate to supervise the expansion of credit institutions to remote geographical areas. Furthermore, given the weak accounting and auditing environment, the BM should ensure capacity exists to monitor and enforce IFRS requirements, as well as to deal with reconciling IFRS and prudential requirements (as recommended by the 2008 Accounting and Auditing ROSC).

\section{B. Financial Safety Nets}

37. The planned deposit insurance scheme should not be introduced before the key preconditions are in place. The BM has drafted a deposit insurance fund (pay-box) proposal, currently being reviewed by the government, with a view to having it approved by year-end. In broad terms, the key elements of this proposal appear to conform to best practice. ${ }^{13}$ However, before the authorities approve it, they should conduct a thorough assessment of the proposed scheme against the International Association of Deposit Insurers core principles. More importantly, since a DIS can increase moral hazard and the contingent liabilities of the government, the authorities should ensure that the preconditions for a sound scheme are in place before it is introduced, notably no pre-existing problem institutions; effective supervision; and strong remedial action and resolution frameworks.

38. Although key components appear to be in place, the entire crisis management and bank resolution framework needs to be carefully reviewed.

- $\quad$ The framework for supervisory administration and bank liquidation may need to be clarified. The banking law allows the BM to designate an administrator (and remove the banks' management if necessary) to restructure a problem bank, and the bank liquidation law allows it to initiate administrative liquidation to sell-off its assets. However, neither the timeframe nor the criteria for initiating liquidation are sufficiently clear. ${ }^{14}$ Moreover, the authorities' ability to create a bridge bank or do a timely partial purchase and assumption is questionable: it would take a long time to verify liabilities, and it is not clear whether the current legal framework allows differential treatment of creditors, which may be needed for a successful resolution.

\footnotetext{
${ }^{13}$ The FSAP mission received only an executive summary of the proposal and did not discuss in detail all technical aspects that would be required for a full assessment. Elements in line with best practice include mandatory participation of supervised banks, exclusion of related-party deposits, partly risk-based premia).

14 This is also related to the lack of an effective remedial action framework.
} 
- $\quad$ The BM should consider a comprehensive and explicit emergency liquidity assistance (ELA) framework. The law grants the central bank the power to provide liquidity assistance for up to 180 days; discount short-term securities (e.g., trade credits); and give credit against a limited range of collateral, e.g., mostly government securities. ${ }^{15}$ However, the BM has only established an overnight standing facility (FPC). An explicit ELA policy would specify the principles and procedures to be followed in case of an acute liquidity problem in normal times (assistance to be given only to illiquid but solvent banks, against adequate collateral, and as a last resort), as well as in case of a critically undercapitalized but systemically important bank, or in a crisis.

- $\quad$ The authorities should develop a crisis management plan, in particular for systemic banks. The authorities should review the legal framework to ensure they have effective powers and procedures for the failure of a large, systemically important bank, including addressing specifically the issue of public funds and coordination with foreign supervisors, central banks, and treasury authorities. In cooperation with the Finance Ministry, the BM should develop contingency planning and testing.

\section{Central Bank Operations, Markets and Payments Infrastructure}

\section{A. Financial Markets and Central Bank Operations}

39. Deep and liquid money and public debt markets are important for monetary stability and financial intermediation. At the time of the 2003 FSAP, high and volatile interest rates and weaknesses in the monetary policy framework threatened monetary stability and the development of the financial sector, encouraged dollarization, and raised the cost of domestic public debt. Since then, major progress has been made in these areas, as evidenced by the successful introduction of a monetary targeting framework and marketbased instruments; the growth of the interbank market; the gradual liberalization of the foreign exchange market, new regulations, and Code of Conduct for participants; advances in de-dollarization; and the reduction in inflation, interest rates, and interest spreads. Positive signs have also arisen lately in the area of public debt management, such as a successful bond issuance in 2008 and the preparation, for the first time, of an Annual Report on Public Debt.

\section{But Mozambican financial markets are still thin and operate under the constraints implied by the structure of the financial system and the monetary policy implementation framework.}

\footnotetext{
15 Acceptable collateral is gold and domestic and foreign government or government-guaranteed securities, in domestic or foreign currency, quoted on the stock exchanges of the principal financial markets.
} 
- $\quad$ The interbank money market (MMI) and the treasury bills (BT) secondary market are the only markets showing some activity. ${ }^{16}$ But even those are very shallow: the BT secondary market had 147 transactions in 2008, totaling MT 4.5 billion; the interbank money market was more active, with MT 52 billion traded (Figure 8). The market for government OT is small and illiquid: only sixteen trades were recorded in 2008, totaling MT 300 million. Custody of OTs is provided by the stock exchange (BVM) in dematerialized form, but Mozambique Stock Exchange (BVM)'s computers are not connected to those of the BM, where the RTGS system and the custody system for BTs run. This prevents delivery-versus-payment (DVP) in OT transactions and makes it harder to use these bonds for repos.

Figure 8. Mozambique: Monthly Number of Trades and Amount Traded in MMI (MT million)

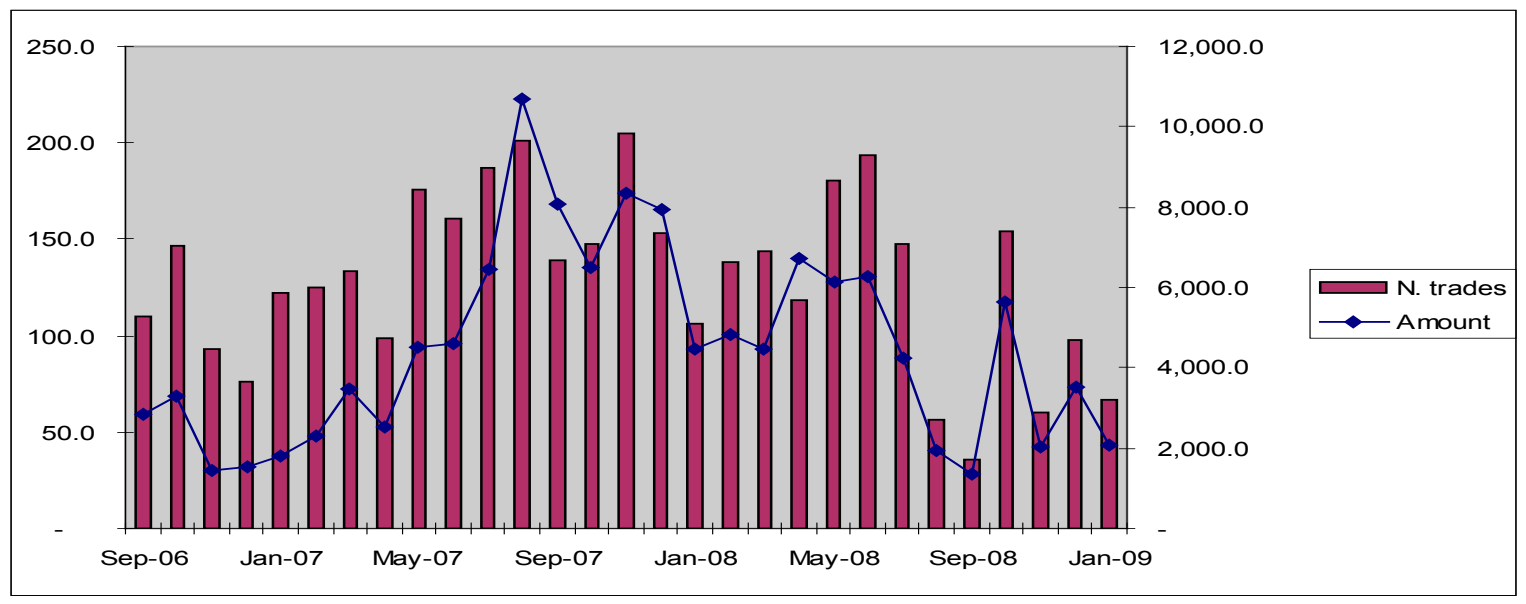

Source: Bank of Mozambique.

- $\quad$ The only instrument the BM uses for liquidity injection is the FPC, which is seen by the market as a ceiling for BT auctions. In a very concentrated market and in the absence of a deep secondary market, such a ceiling leads to distortions in the behavior of primary auction rates (Figure 9). Moreover, the absence of a liquidity provision instrument at market rates induces banks to hoard liquidity, reducing the chances that complementary positions appear in the money market. Banks spread out their holdings of BT so that almost every week there are bills coming due; temporary excesses are placed in the standing deposit facility (FPD), in amounts which, although

\footnotetext{
${ }^{16}$ The stock market is still in its infancy. Just thirteen securities are listed in the stock exchange: five treasury bonds (total amount MTN 3 billion) and seven corporate bonds from five companies. Only one company has listed shares. There are no active mutual funds or brokerage houses - brokers in the stock exchange are the biggest banks. Despite efforts to develop the private pension fund industry, its presence in the market is still very limited. Capital controls prevent foreigners from entering the market.
} 
small when compared to BTs, are equivalent to 20 percent of bank reserves and have been growing recently.

- $\quad$ Liquidity forecasting is excessively focused on the short term. The BM is currently undertaking two forecasting exercises: one conducted by the Markets Department (DEM) on a daily basis and focused on one maintenance period of required reserves; and the other performed by the Economic Studies Department (DEE), with a 3-month horizon, providing guidance to the DEM on its interventions for structural liquidity management through sales of BT and foreign exchange. There is no regular longerterm liquidity forecasting exercise.

41. The key policy challenge here is to improve trading liquidity. First, more trading liquidity would mean greater facility changing assets for cash or financing those assets through repos. Second, it would help reduce interest rates through the decrease of the liquidity premium. And third, it would provide the basis for a market-based yield curve. A market yield curve, in turn, is key for the development of capital markets and for efficient monetary policy transmission. Steps to improve trading liquidity fall into two categories.

Figure 9. Mozambique: Interest Rates, 2007-09

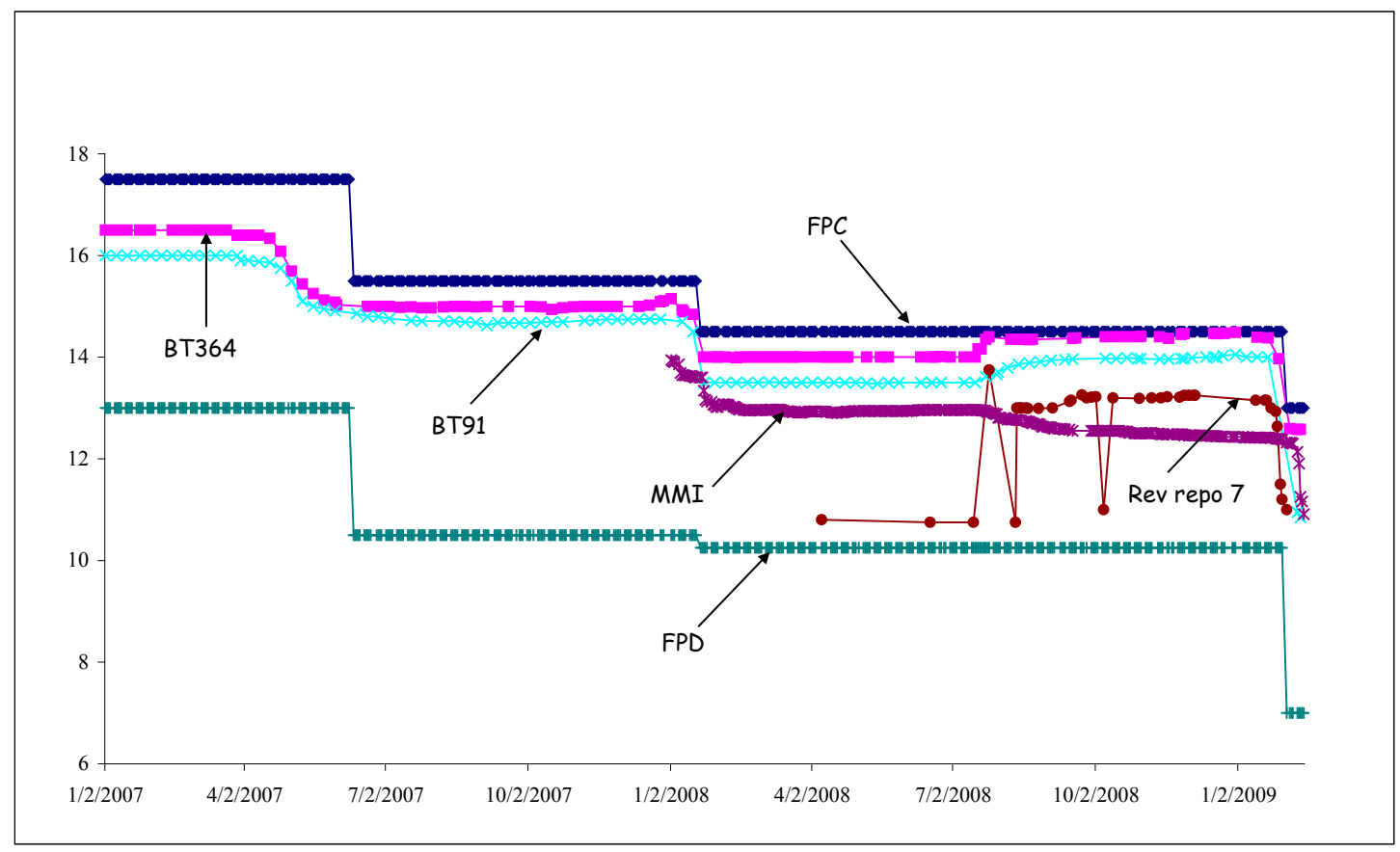

Source: Bank of Mozambique. 


\section{Central bank liquidity management}

- $\quad$ The medium-term liquidity exercise needs to be extended to one year. For one or two quarters, base money has to be forecast from current and past conditions; only for longer periods, the base money target - and other monetary program targets - can be treated as an input. Forecasts of government flows should be coordinated with monthly or - at least - quarterly reviews of the plan prepared by the Treasury for the fiscal year. BT issuance should be based on this exercise and be consistent with the estimated evolution of the rest of BM's balance sheet. As confidence in medium-term forecasting builds up, a BT auction schedule — with dates, maturities, and amountsshould start being published regularly, to allow investors to better plan their participation. When setting up this schedule, the BM should space out auctions for the same term, thus helping increase competition in those auctions.

- $\quad$ The implicit ceiling for BT auction rates should be removed. While the FPC should continue to function as a ceiling for the very short-term interest rates, the longer-term rates should reflect market expectations. The BM would still be able to deal with instances of oligopolistic behavior by rejecting part or all of the bids in an auction. (although the number of such events should be kept to a minimum). The BM should not open a second auction when demand is greater than the amount offered: the unattended bids will add to demand in subsequently scheduled auctions.

- The BM should use overnight repo and reverse repo auctions for intervention, guided by the short-term liquidity forecast. In both cases, the intervention should have a one-day term and its cut-off rate be close to the interbank overnight rate. Banks' confidence that BM stands ready to inject liquidity at reasonable rates in the event of an aggregate shortage should motivate them to reduce their liquidity cushions, facilitating the development of the money market.

\section{Market development}

- $\quad$ To encourage the use of repos among market participants, the BM could collateralize the FPD. ${ }^{17}$ This would allow a bank to intermediate liquidity excesses of other counterparts - that may or may not have an account with this bank-towards the central bank deposit facility.

- $\quad$ Both the BM and the MOF should start to issue fungible securities, ${ }^{18}$ thus reducing the number of outstanding maturities. This is a way to start creating market benchmarks with higher outstanding volumes, which will tend to be more liquid than

\footnotetext{
${ }^{17}$ To this end, the BM's holdings of perpetual government bonds could be swapped with marketable instruments.

${ }^{18}$ Fungible securities have identical face value, coupon value, maturity date, and coupon payment dates.
} 
many different bills and bonds with low outstanding volumes. It would also allow regular auctions without an excessive number of different securities outstanding.

- Information on public debt should be improved through the publication of a consolidated BT/OT issuance calendar, information on outstanding debt, and data on primary and secondary market trading.

- $\quad$ An increase in the stock of outstanding OTs would stimulate market development without increasing the net public debt if the proceeds are not spent. The amounts issued at BT auctions could then be reduced, intensifying competition for those instruments. Moreover, issuing fixed instead of floating rate bonds would provide the basis for lengthening the yield curve beyond one year.

- A number of measures should also be considered to strengthen custody, settlement, and trading arrangements, notably creating conditions for trades to take place between a bank and a client of another bank; ensuring DVP settlement of transactions originated at the Stock Exchange (see following Section); and unifying BT and OT custody.

\section{B. Payments System}

42. Since the 2003 FSAP, Mozambique has made considerable progress in improving its national payments system. Mozambique introduced the government electronic funds transfer system (EFTS) in 2004, which replaced the non-encoded payment orders and Titulos transactions that were previously processed through the CEL system; upgraded the CEL system to allow for electronic clearing by its 17 participants; promulgated the National Payment System (NPS) Act in October 2007; strengthened the regulations for interbank clearing and settlement; introduced the Sistema de Transferencia de Fundos do Estado (STF) - a real-time system used by Government for payments, including salaries for the civil service; and although still inadequately staffed, the Payment Systems Division now has a staff complement of six, an improvement from the two staff manning the Unit in 2003. In addition, the 2007 NPS law strengthened the legal basis for the payment system and paved the way for the introduction of RTGS.

43. Today, pending full implementation of RTGS, the CEL remains the main settlement system, with the BM providing settlement arrangements for participants. The CEL system is still used to settle obligations arising from the cheque payment stream, government EFTS, ATM, and POS networks, and the stock exchange (BVM). Using seven branches and the head office in Maputo, the BM facilitates the clearing of cheques and the distribution of cash throughout the country. Although cheques and electronic fund transfers are the main means of payment, cash still accounts for a significant proportion of payment transactions and banking costs.

44. In this transitional phase, the key priority is to continue to monitor the risks inherent in the CEL system and complete the implementation of RTGS. CEL operates on 
a deferred net settlement (DNS) basis; i.e., settlement takes place a day after the transactions are processed through the system. This settlement lag can be a source of liquidity and credit risk, especially since the requirement for participants to lodge collateral as a condition for participating in CEL system has never been enforced. Although the introduction of the RTGS system will reduce this risk, the BM should remain vigilant and monitor risks within CEL, as long as the latter remains systemically important. Looking forward, regulations that are needed to complete the transition to RTGS should be issued as soon as possible.

\section{In addition, priority should be given to the following areas.}

- $\quad$ The BM should design and adopt a framework for the oversight of payment systems and build further capacity in the payments system unit.

- $\quad$ Securities settlement should be accelerated. Although the BVM has electronic systems that support its operations, the current settlement arrangements are slow because of the manual intervention that requires the BM to re-capture net obligations onto the CEL system. The BM, in cooperation with the BVM and its brokers, should establish the electronic link that would reduce the settlement cycle and facilitate the achievement of DVP (see also previous Section).

- $\quad$ The BM should clarify its position on the interoperability of bank cards and consider the sharing of retail payments infrastructure. While some debit cards are interoperable at the moment, the fees charged for ATM cash withdrawals across banks are high. A national switch would facilitate the removal of this rigidity. The $\mathrm{BM}$ should consider encouraging this and using moral suasion to get banks to cooperate on this matter through the Payment Systems Forum. The BM should also clarify its views on participation by mobile phone providers and other third parties in the payments area. 


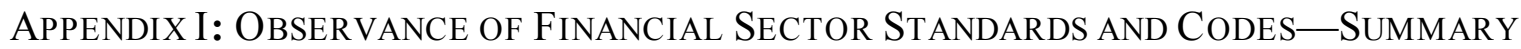 Assessment of BASEl CoRe PRINCIPLES FOR EFFECTIVE BANKING SUPERVISION}

46. Since the 2003 BCP assessment, compliance has been significantly improved, although some important areas require strengthening. Key enhancements to the framework include a major revision to the Banking Law; promulgation of the AML law; a new inspection manual; and the implementation of IFRS for banks. Home-host supervisory relationships were also strengthened. Furthermore, the number of supervisory staff has increased substantially and great emphasis placed in training. Overall, an adequate regulatory framework for bank supervision has been adopted and the supervisory authority has a good overview of individual institutions and the sector as a whole. Despite this progress, important shortcomings remain, especially in the areas of loan classification and provisioning, assessments for risks other than credit, and effective use of remedial action powers. Furthermore, the level of home-host coordination could be increased further given the systemic importance of foreign-owned banks.

\section{Introduction}

47. A full assessment of the BCP was carried out as part of the joint IMF/World Bank FSAP Update for Mozambique. The assessment was conducted by Ms. Ana Rita Mateus (Bank of Portugal) and Mr. José Tuya (formerly Office of the Comptroller of the Currency).

\section{Information and methodology used for the assessment}

48. The FSAP Update reviewed relevant legislation, regulation and documentation, in line with the review conducted for the 2003 FSAP. The review included the Banking Law (BL - Law no. 15/1999 of November 1), which was revised in 2004 by Law no. 9/2004 of July 21, and the Central Bank Law (Law 1/92 of January 3), which has not yet been revised. The BCP assessment also reviewed other relevant laws, as well as the decrees, regulations (Notices - "Avisos"), and supervisory guidelines (Circulares) issued by BM. It also analyzed internal documents prepared by BM, namely supervisory manuals, examination reports, off-site reports, working documents, the website and other relevant material, and benefited from discussions with senior officers and staff of the BM and external parties, such as banks and external auditors. The Mozambican authorities were cooperative and helpful.

\section{In preparing this report, the assessors used the $\mathbf{2 0 0 6}$ Core Principles}

Methodology and in accordance with the recommendation of the Basel Committee on Banking Supervision (BCBS), the assessment was conducted by two experts. 


\section{Institutional and macroeconomic setting and market structure}

50. $\quad B M$ is responsible for the supervision of credit institutions and financial

companies. Banking supervision is operationally conducted through the BM's BSD, whose responsibilities are detailed in the BL.

\section{The supervisory framework includes:}

- the Banking Law, which sets the basis for supervision;

- requirements on capital adequacy, including a minimum CAR of 8 percent;

- generic requirements on internal controls;

- minimum levels of provisions;

- restrictions on connected lending;

- large exposures and concentration limits;

- limits on foreign exchange exposures;

- minimum reserve requirements;

- limits on fixed assets;

- powers to conduct off-site inspections and demand for accurate information regularly; and

- powers to impose sanctions and remedial actions.

52. Noticeable regulatory developments since the 2003 FSAP include:

- revision of the Banking Law that enhanced BM's supervisory, enforcement and remedial powers;

- revision of the provisioning system;

- introduction of rules for consolidated supervision;

- regulation of the AML law; and

- introduction of IFRS.

53. Among BM-regulated institutions, only banks, credit cooperatives or microbanks can currently take deposits. Credit institutions encompass banks, credit cooperatives, investment companies, factoring companies, dealers, micro-banks and others defined by specific regulation. Financial companies can take the form of broker dealers, wealth management companies, risk venture companies, investment funds management companies, credit card companies and exchange bureaus. Currently, there are 21 deposittaking institutions, 22 exchange bureaus and 5 other financial companies (FSSA Table 2).

\section{The Mozambican banking system is highly concentrated and mostly foreign} owned, although some state participation remains. The largest bank, represents around 40 percent of the market and the four largest banks together represent over 90 percent of the banking system. The owners of these banks are mostly Portuguese or South African (FSSA 
Table 3 ). There is only one small domestic private bank. Other banks are owned by financial institutions from Mauritius, Botswana, Macau and Malaysia, while some smaller institutions are owned by non-financial institutions, sometimes by NGOs (mostly with capital from Germany and USA). The state maintains a minority participation of 23 percent (including worker participation) in the largest bank, while the INSS controls one small bank.

\section{Preconditions for effective banking supervision}

55. Banks face important constraints when investing their funds. While macroeconomic policies are sound and sustainable, public infrastructure, market discipline, and mechanisms to provide systemic protection still need further strengthening. Judicial, legal and information constraints still limit safe credit opportunities. Investments abroad, such as in credit and financial instruments, require an authorization from BM and local financial assets are limited to public debt instruments. This creates an incentive for institutions to place a significant amount of claims in their parent company outside the country.

56. While there has been some improvement in lending practices, credit risk management still appears relatively weak. Since the 2003 FSAP, banks have increased their focus on borrower capacity to repay loans, rather than relying on guarantees as a credit risk mitigant. This notwithstanding, NPLs indicators still vary substantially between periods and are fairly high for some banking institutions. The lack of broader based creditor information (e.g., credit rating companies) remains a constraint.

57. The judicial system hinders effectiveness, particularly with respect to enforcement of creditor rights. Even though commercial courts were created in the last few years to accelerate the debt (collateral) recovery process, they do not always work well in practice. Furthermore, the corporate bankruptcy and liquidation laws still need to be updated. Thus, banks rarely attempt to execute their rights as creditors, since they claim it is preferable either to accept the loss or to renegotiate the loan.

58. Commercial companies are not required to have their annual accounts certified by an external auditor. This undermines the reliability and credibility of data and makes credit decisions more difficult, in particular with respect to small companies.

\section{Main findings}

59. There has been significant improvement in compliance with the Basel Core Principles for BCP since the 2003 FSAP. The most significant area of improvement has been in the development of regulation and supervisory guidelines. The BM has also started to 
move away from a regulatory compliance focus to a more risk-based supervision. Overall, an adequate regulatory framework for bank supervision has been adopted.

60. BM seems to have a good overview of individual institutions and the Mozambican banking sector as a whole. Regular reports and analysis of the financial situation help provide an up-to-date view of each institution, and more detailed insights are acquired through yearly on-site inspections. This framework allows BM to detect areas or flaws to be addressed, and it is common procedure, mainly after on-site inspections, for the BSD to recommend necessary actions.

\section{Despite this progress, important shortcomings remain.}

- The current loan classification and provisioning regulation does not provide an early warning as to deteriorating trends since the time-based classification and provisioning buckets are so wide. The regulation needs to be amended and establishment of loan loss provisions be made more risk-sensitive.

- $\quad$ BM practices in supervising interest rate, country, liquidity, and market risk and AML are weak. Some of these areas are not regulated at all, while in other areas, the regulations do not always have attendant guidance to aid BM staff in monitoring compliance or to provide banks with the minimum requirements they are expected to meet when developing risk management systems or internal policies and procedures.

- $\quad$ The structure of the Mozambican banking system presents two particular regulatory challenges for BM. BM needs to have strong cross-border collaboration with home country supervisors. The BM also needs to review parent company systems, and determine their applicability and adequacy for the Mozambican branch or subsidiary.

- The BM has not used effectively its powers to induce substantive remedial and corrective actions. Supervisors have allowed a small bank to continue operating although it has been in financial distress for a long time; similarly, no corrective actions have been taken with respect to other small credit institutions whose credit portfolio is of poor quality. Even though these institutions are not systemically important, BM's inability or unwillingness to act decisively raises questions about its credibility. Thus, while the BM ensures that minor remedial actions are addressed by management, it is very slow to act when important problems occur at a bank, such as insufficient capital and/or inadequate provisioning of assets. 
62. In tackling these challenges, the BM should make greater use of best practice guidelines. The BM has issued a number of regulations requiring the implementation of important processes, e.g., for internal controls and credit risk management. However, the BM has not issued guidelines setting best practice in these areas. With respect to liquidity risk management, the BM should provide banks with the critical elements needed to ensure that systems meet the requirements of the BM. Best practices should also be incorporated into the inspectors' manuals to monitor compliance.

63. The BM is trying to move to a more risk-base supervisory framework and plans to implement Basel II in the near future. The need for further action in this respect is specified under the respective principles.

\section{Principle-by-principle assessment}

Objectives, independence, powers, transparency and cooperation (CP 1).

\section{The regulatory framework provides the BM with a clear delineation of its} supervisory domain, independence and the powers to carry-out its function. Since the 2003 FSAP, the BL was amended and a number of regulations issued, forming a compendium that properly supports the supervisory function. The amendments to the BL addressed most of the legal deficiencies noted in 2003 and strengthened the independence of the BM. In addition, a law was passed criminalizing money laundering, and a bank liquidation law was passed that clearly delineates the power of the BM to declare a bank bankrupt and initiate administrative liquidation. International Financial Reporting Standards have also been implemented, improving the transparency of financial statements.

\section{Licensing and structure criteria (CP 2 to 5).}

65. The legislation sets out clearly the permissible activities of banks and the licensing provisions were amended to give the BM sole authority to license banks. The amendments to the BL also give the BM the authority to request information on the source of initial capital, ability to meet capital adequacy requirements and supervisory and regulatory requirements in the home jurisdiction.

66. The BL states that any ownership equal or above 10 per cent shall be considered as a "significant ownership." In this context, ownership means voting rights and associated or group companies, as well as family relationships, are grouped together for this purpose. In addition, the BL requires notification of changes in the percentage of significant ownership and an annual communication of the names and ownership percentages of all shareholders that own a significant stake. 


\section{Prudential regulation and requirements (CP 6 to 18)}

67. Minimum capital rules are broadly consistent with international standards (Basel I) and the BM is currently planning for the implementation of Basel II. However, the BM does not require institutions to self-assess the amount of capital they hold against their risk profile, nor does it require institutions to hold capital for market risk or in excess of minimum capital to reflect a high risk profile.

68. In 1999, the BM issued a regulation requiring banks to have internal control systems and required that such systems and policies be approved by the board of directors. However, supervisory policies or guidance establishing the criteria for evaluating the adequacy for the internal control system were not issued. Currently a project is underway to develop a set of criteria to provide guidance on the minimum standards for bank risk management systems.

69. An inspections manual has been implemented that expands the scope of credit reviews to include bank policies and internal controls to manage risk. In on-site inspections, BM inspectors usually analyze the compliance of granting credit practices with the pre-defined internal policies. They also assess the existence and quality of credit policies, practices and procedures.

70. Loan classification and provisioning requirements are calculated based on the time that the loan has been past due. A loan payment is classified substandard after one day past due and remains classified substandard until the $180^{\text {th }}$ day of past due status. A more risk sensitive and proactive method would be to classify loans based on credit analysis and to reduce the number of days in each classification time band. In addition, when a payment is past due, the entire principal of the loan should be subject to classification and provisioning and not just the payment amount. The classification should reflect the quality of the borrower and therefore the entire balance is of doubtful collection and not just a payment. Furthermore, the BM should establish a requirement to put NPLs on non-accrual.

71. The definitions of large exposure as $\mathbf{1 0}$ percent or more of the own funds of the institution and the limits on individual large exposures at 25 percent of the institution's own funds are consistent with the international guidelines.

72. There is a lack of adequate guidance and supervisory review in the areas of liquidity, interest rate, country, market and operational risk. Although the BM has established limits on open currency positions and collects information on liquidity, it has not developed a comprehensive process to monitor, measure and set standards in these areas. Currently, as part of its supervision by risk guidelines that are under development, and as part of Basel II implementation, the BM plans to address many of the deficiencies in these areas. 
73. The BM issued internal control guidelines and reviews these during onsite inspections, but the BM lacks authority to require banks to have an internal audit function. Nevertheless, the work of the internal audit is reviewed during inspections and the inspection reports highlight the deficiencies found.

74. The anti-money laundering regulations establish know your customer requirements and suspicious transactions reporting by financial institutions. The law enforcement authority is responsible for deciding whether an investigation is required after reviewing the report. The BM has received training from the IMF on AML, and in 2006 four on-site inspections were conducted with the involvement of the Fund. Currently, a World Bank consultancy project is under way to train BM inspectors on AML, but since 2006 no specific inspections have been conducted. The lack of onsite inspections and offsite monitoring for compliance with the AML law makes it impossible for the BM to monitor and ensure compliance.

\section{Methods of ongoing banking supervision (CP 19 to 21)}

75. The BM has implemented major enhancements to its supervisory process since the previous FSAP. An examination manual has been developed that provides the inspectors with a methodical process to review bank functions, document results and report. The onsite inspection teams have been enhanced by adding information technology experts. Overall the onsite and offsite process provides a good foundation for the continued development of the supervisory function. The process should be further enhanced by improving the coverage of risks outside the credit area, e.g., liquidity and interest rate risks.

\section{Accounting and disclosure (CP 22)}

76. In 2007, the BM established the requirement that supervised institutions report their financial statements based on IAS. Some small institutions may be granted exemption from filing under IAS for reasons of size, geographical location or others. In addition, filing requirements include the use of BM established formats for financial statements to facilitate processing and analysis. Supervised institutions are required to publish their audited balance sheets in a widely-read newspaper and the institution's website.

\section{Corrective and remedial powers of supervisors (CP 23)}

77. The BM has a broad range of sanctioning and enforcement powers. However, there is lack of detailed guidance on the application of graduated remedial action. Supervisors should have a well-defined range of tools for use when a bank is not complying 
with legal requirements or is engaged in unsafe and unsound practices. The guidance should address how the tools are applied in accordance with the gravity of the situation.

Consolidated and cross-border banking supervision (CP 24 and 25)

\section{Regulations establish that all institutions supervised by $\mathbf{B M}$ are subject to} supervision on a consolidated basis. The accounting rules support a consolidated view of the balance sheets. However, almost all banks operate on a solo basis without subsidiaries.

79. The BM continues to enhance its home-host relationships and has completed MOU with some countries. During the licensing process there is an exchange of correspondence as information on the applicant bank is requested. In addition, there are frequent communications with Portugal and South Africa, the two main home counterparts to the BM. Given that there are no established country risk guidelines and that almost all banks are foreign-owned, the BM should continue to develop its relationships with key home country regulators to get their views on the soundness of their banks in Mozambique. 


\section{Table 8. Summary Compliance with the Basel Core Principles-Summary Assessments}

\begin{tabular}{|c|c|}
\hline Core Principle & Comments \\
\hline \multicolumn{2}{|l|}{$\begin{array}{l}\text { 1. Objectives, independence, powers, transparency, } \\
\text { and cooperation }\end{array}$} \\
\hline 1.1 Responsibilities and objectives & Licensing is now independently done by BM. \\
\hline 1.2 Independence, accountability and transparency & $\begin{array}{l}\text { The revisions to the BL in } 2004 \text { provided the BM with } \\
\text { operational independence. }\end{array}$ \\
\hline 1.3 Legal framework & The BL provides adequate powers to the BM. \\
\hline 1.4 Legal powers & BM has adequate sanction and remedial powers. \\
\hline 1.5 Legal protection & $\begin{array}{l}\text { BSD staff is protected from legal liability in the } \\
\text { performance of its duties. }\end{array}$ \\
\hline 1.6 Cooperation & MOUs and informal arrangements are now in place. \\
\hline 2. Permissible activities & Fully defined in legislation. \\
\hline 3. Licensing criteria & $\begin{array}{l}\text { Amendments to BL addressed deficiencies noted in } \\
2003 \text { FSAP. }\end{array}$ \\
\hline 4. Transfer of significant ownership & Adequate legal framework. \\
\hline 5. Major acquisitions & All criteria are addressed. \\
\hline 6. Capital adequacy & $\begin{array}{l}\text { Does not cover market risk, nor the requirement of an } \\
\text { internal capital adequacy assessment. }\end{array}$ \\
\hline 7. Risk management process & Inadequate guidance provided to banks and inspectors. \\
\hline 8. Credit risk & $\begin{array}{l}\text { Guidance should be provided on evaluating credit risk } \\
\text { management. }\end{array}$ \\
\hline 9. Problem assets, provisions, and reserves & $\begin{array}{l}\text { Guidance needed for inspectors to evaluate credit risk } \\
\text { management. }\end{array}$ \\
\hline 10. Large exposure limits & $\begin{array}{l}\text { Limits established, but in practice do not consider } \\
\text { exposures other than credit or guarantees. }\end{array}$ \\
\hline 11. Exposure to related parties & Regulation in place. \\
\hline 12. Country and transfer risks & $\begin{array}{l}\text { BM does not monitor and has not issued guidance on } \\
\text { country risk. }\end{array}$ \\
\hline 13. Market risks & Supervisory guidance or monitoring does not yet exist. \\
\hline 14. Liquidity risk & $\begin{array}{l}\text { BM does not have sound procedures to estimate the } \\
\text { level of liquidity risk. }\end{array}$ \\
\hline 15. Operational risk & Limited guidance has been issued. \\
\hline 16. Interest rate risk in the banking book & $\begin{array}{l}\text { There has not been sufficient guidance issued on } \\
\text { measuring this risk. }\end{array}$ \\
\hline 17. Internal control and audit & $\begin{array}{l}\text { Existing guidance should be updated to include other } \\
\text { risks, namely omitted types of operational risks. }\end{array}$ \\
\hline 18. Abuse of financial services & $\begin{array}{l}\text { Onsite procedures and inspections have not been } \\
\text { implemented. }\end{array}$ \\
\hline 19. Supervisory approach & $\begin{array}{l}\text { The existing process does not cover the full spectrum of } \\
\text { banking risks. }\end{array}$ \\
\hline
\end{tabular}




\begin{tabular}{|l|l|}
\hline 20. Supervisory techniques & $\begin{array}{l}\text { Significant improvements since 2003: technical } \\
\text { requirements of CP are met. }\end{array}$ \\
\hline 21. Supervisory reporting & $\begin{array}{l}\text { BM has the authority to collect all needed information } \\
\text { and this is indeed collected. }\end{array}$ \\
\hline 22. Accounting and disclosure & IFRS has been implemented. \\
\hline 23. Corrective and remedial powers of supervisors & $\begin{array}{l}\text { More effective use of available of available powers is } \\
\text { needed. }\end{array}$ \\
\hline 24. Consolidated supervision & Implemented since 2003 FSAP \\
\hline 25. Home-host relationships & $\begin{array}{l}\text { MOUs signed and increased communications take } \\
\text { place. }\end{array}$ \\
\hline
\end{tabular}

\section{Recommended action plan}

\section{Table 9. Recommended Action Plan to Improve Compliance with the Basel Core Principles}

\begin{tabular}{|l|l|}
\hline \multicolumn{1}{|c|}{ Reference Principle } & \multicolumn{1}{|c|}{ Recommended Action } \\
\hline CP 9- Problem assets, provisioning and reserves & $\begin{array}{l}\text { Classification and provisioning needs to be made more } \\
\text { risk-sensitive: for example, in its inspections and } \\
\text { monitoring, additional provisions should be required } \\
\text { not only for compliance lapses but for deterioration in } \\
\text { the borrower's financial condition. It is also } \\
\text { recommended that a non-accrual requirement be } \\
\text { instituted for loans 90 days or more delinquent. }\end{array}$ \\
\hline $\begin{array}{l}\text { CP 7, 12-16 and 18- Risk monitoring and } \\
\text { management }\end{array}$ & $\begin{array}{l}\text { These principles share a common deficiency: a lack of } \\
\text { regulations and/or guidelines for monitoring and } \\
\text { inspecting. Guidance/regulations to aid BM staff in } \\
\text { monitoring compliance or to provide banks with the } \\
\text { minimum requirements they are expected to meet } \\
\text { when developing risk management systems or internal } \\
\text { policies and procedures need to be developed. }\end{array}$ \\
\hline $\begin{array}{l}\text { CP 23-Corrective and remedial powers of } \\
\text { supervisors }\end{array}$ & $\begin{array}{l}\text { An effective remedial action program with defined } \\
\text { remedial steps is needed to have more systematic } \\
\text { process to identify and penalize poor management, and } \\
\text { remove ineffective or unsound managers from the } \\
\text { system. }\end{array}$ \\
\hline CP 25 - Home-host relationships & $\begin{array}{l}\text { Increase the level of coordination to: establish } \\
\text { contingency planning for crises, and determine the } \\
\text { strength of support that may be available from the } \\
\text { parent company or government, the home country } \\
\text { rules in a bankruptcy situation and economic } \\
\text { conditions in the home country. }\end{array}$ \\
\hline
\end{tabular}




\section{Authorities' response to the assessment}

The BM agreed with most of the recommendations, noting that many are starting to be implemented. To facilitate the implementation of the remedial action recommendation, the $\mathrm{BM}$ requested further elaboration on country practices. On regulating risks other than credit, the BM indicated that the need will be determined based on BM's assessment of banks' risk management practices and of systemically important risks. The BM observed that the current regulations on loan classification and provisioning were changed in 2005 in line with what it believed was the recommendation of the 2003 FSAP. 


\section{Appendix II: A Remedial Action Program for MozambiQue}

80. The 2003 FSAP noted that although the BM had the legal authority to take remedial actions, it had used this authority sparingly. This situation remains the same today, with a dearth of remedial actions even when patently warranted. An explicit Remedial Action Program would help address this shortcoming, although it would also be ineffective if the will to take action is lacking.

81. An appropriate Remedial Action Program must have well defined enforcement tools that enable the regulator to apply a wide range of penalties or restrictions that can be adapted to the gravity of the situation. The program must be transparent: the BM should publish the situations under which it would take supervisory action, and describe the supervisory action and the subsequent response should the institution fail to act. Internal operating procedures at the BM should be detailed and prescriptive, describing the officials responsible for initiating the action, the process to be followed starting at the field inspector level, the review process, and establishing processing timeframes. In its annual report, the BM should publish the remedial actions taken even if the name of the institution is withheld. Having a transparent, well-defined process with benchmarks and reporting will enhance supervisory accountability.

82. The initiation of remedial action should be specifically linked to capital, reporting, adequacy of bank policies and risk management, violations of law, and bank performance (CAMEL). The published guidelines should establish that banks can expect an action when:

- $\quad$ Capital falls below a certain level. The action can vary depending on the trigger points and management response.

- A regulatory report is over 30 days delinquent or contains inaccuracies. A daily fine can be imposed until situation is corrected.

- $\quad$ Bank operating policies and processes are inadequate and lead to a deteriorating financial condition. The action can initially be an order from the BM requiring the bank to fix the problem, and providing a listing of the BM concerns. The order should provide a timeframe for the corrective action and a stepped-up penalty in case of noncompliance.

- Violations of law are identified. Depending on their gravity, some violations, such as connected lending, should have automatic fines on the bank and the individual.

- $\quad$ Bank soundness falls below acceptable levels established by the BM. The BM should communicate to the bank its concerns, provide a timeframe to implement its recommendations, and instruct the bank to cease and desist practices that the BM considers unsafe and unsound. 
83. The published guidelines should make it clear that the ultimate action, if the bank does not comply with $\mathrm{BM}$ remedial actions, will be intervention, liquidation, or forced sale/merger. But it is important that the remedial actions be initiated with an early identification of the problem to allow for early correction, avoid asset dissipation, and arrest deterioration at an early stage.

84. A detailed Remedial Action Program will enhance accountability, as those involved will need to document why action was not taken in the presence of the situations described above. The BM internal audit or internal control system should review the Remedial Action Program and its implementation. 